\title{
Las dos versiones de la De Psalterii Anglicani exemplari animaduersio de Benito Arias Montano en la Biblia Políglota de Amberes*
}

\author{
Antonio Dávila Pérez** \\ Universidad de Cádiz
}

En el octavo y último volumen de la Biblia Regia de Amberes Benito Arias Montano publicaba un breve texto titulado De Psalterii Anglicani exemplari animaduersio. En el marco de su defensa del original hebreo del Antiguo Testamento, su autor consideraba necesario advertir al lector de que algunos de los manuscritos más apreciados por los llamados «misohebreos» de su tiempo carecían de todo valor. Para ello, Arias Montano examinó un manuscrito hebreo del salterio elogiado como muy antiguo y relevante por el poderoso obispo Guillermo D. Lindano, y concluía que el códice era reciente y de escaso valor, cargando de paso contra la reputación científica de este. El ataque, fundamentado en parte en una falsa denuncia, sería el punto de partida de una controversia personal y científica que se extiende durate más de quince años. El presente artículo llama la atención sobre el hecho de que en los ejemplares conservados de la Políglota se pueden leer dos versiones de la Animaduersio montaniana muy diferentes entre sí. Con objeto de aclarar las circunstancias y motivos que las originaron, el autor propone: (1) reunir en un único estudio, por vez primera, el texto latino y la traducción al español de las dos versiones de la Animaduersio; (2) investigar, a la luz de la correspondencia privada de Arias Montano y de Lindano, las razones que propiciaron la existencia de dos versiones tan distintas de este prefacio; (3) y conjeturar una datación aproximada para cada una de las versiones.

Palabras Clave: Humanismo; filología bíblica del siglo XVI; Biblia Regia de Amberes; epistolografía renacentista.

*El presente trabajo se ha realizado en el marco del Proyecto del Plan Nacional de I+D FFI2012-31097 del Gobierno de España y del Proyecto de Excelencia de la Junta de Andalucía con referencia PAI09-HUM-04858. Asimismo he desarrollado la etapa final de esta investigación en calidad de integrante (uno de los dos miembros españoles designados) del Comité de Gestión de la Acción COST (European Cooperation in Science and Technology) «Reassembling the Republic of Letters, 1500-1800» (ICSH COST Action IS1310). Dicha acción ha puesto en marcha una red científica pan-europea que durante los próximos cuatro 
The Two Versions of the De Psalteril Anglicani Exemplari Animaduersio by Benito Arias Montano in the Antwerp Polyglot Bible.- In the eighth and final volume of the Antwerp Polyglot Arias Montano published a short text titled De Psalterii Anglicani Exemplari Animaduersio. In his defense of the Hebrew original of the Old Testament, Montano set out to warn the reader that some of the more esteemed manuscripts by the so-called Hebrew-haters of his time were of little value. For this purpose, Arias Montano examined a Hebrew manuscript of the Psalter considered to be of particular antiquity and significance by the powerful bishop Wilhelm D. Lindanus, and concluded that it was in fact recent and quite worthless in many aspects, thereby fiercely attacking the latter's scholarly reputation. This attack, based in part on a false accusation, was the beginning of a scholarly controversy lasting over fifteen years. The present essay calls attention to the fact that two versions of the Animaduersio, very different from each other, can be found in surviving copies of the Polyglot Bible. In order to illuminate the circumstances that led to these versions, the author proposes a threefold goal: (1) to gather the Latin text and the Spanish translation of the two versions of the Animaduersio; (2) to examine the reasons why Arias Montano rewrote his text in the light of the private correspondence of both scholars; (3) and to propose an approximate date for each of the versions.

KeYwords: Humanism; $16^{\text {th }}$ Century Biblical Philology; Antwerp Polyglot; Renaissance Epistolography.

A modo de nota final al prefacio del tratado décimo cuarto del tomo octavo (y último) de la Biblia Políglota de Amberes (1569-1573), Benito Arias Montano publicó un breve escrito titulado De Psalterii Anglicani exemplari animaduersio. De este texto podemos encontrar dos versiones impresas, muy

años va a planificar y diseñar un lugar en la red en el que dar cabida y permitir la visualización y análisis de los epistolarios de la Europa de la Temprana Edad Moderna que conforman la conocida como República de las Letras. En este contexto cabe anunciar aquí que nos encontramos en la fase final de ejecución de un ambicioso proyecto, iniciado hacia 1995 bajo la dirección de José María Maestre Maestre, cuyo objetivo es publicar la edición completa de la correspondencia de Benito Arias Montano. Desde 1995 hasta la actualidad distintos investigadores vinculados al grupo de investigación HUM-251 hemos publicado un total de cinco volúmenes de sus cartas así como una larga serie de artículos científicos. Para la tarea final de reunir y revisar todo el material editado junto con el que aún permanece inédito coordino un equipo interdisciplinar de historiadores, hebraístas y filólogos de distintas universidades españolas y extranjeras: Theodor W. Dunkelgrün (Universidad de Cambridge, Reino Unido), Jeanine De Landtsheer (Universidad Católica de Lovaina, Bélgica), Guy Lazure (Universidad de Windsor, Canadá), José María Maestre Maestre (Universidad de Cádiz), Baldomero Macías Rosendo (Universidad de Huelva), Enrique Morales Lara (Universidad de Cádiz) y Bartolomé Pozuelo Calero (Universidad de Cádiz). Agradezco al Dr. Theodor W. Dunkelgrün la atenta lectura del original de este trabajo y las sugerencias con las que lo ha enriquecido.

**antonio.davila@uca.es 
distintas entre sí, en los ejemplares conservados de la Biblia Regia ${ }^{1}$. La versión B de la Animaduersio fue traducida y estudiada por Emilia Fernández Tejero en 1997² ; en 2007 María Asunción Sánchez Manzano editó y tradujo al castellano la versión $\mathrm{A}$, ofreciendo además un cuadro donde recogía los cambios que se introdujeron en la versión $\mathrm{B}$ con respecto a la versión $\mathrm{A}^{3}$. Debo destacar aquí que Sánchez Manzano es la primera investigadora que conecta la existencia de las dos versiones de la Animaduersio con la polémica entre Arias Montano y Guillermo D. Lindano. En 2012 Theodor W. Dunkelgrün dedicó un brillante capítulo a este mismo texto montaniano, realizando valiosas aportaciones sobre las características técnicas y, sobre todo, la historia del manuscrito hebreo del salterio que Arias Montano tuvo entre sus manos, felizmente descubierto por él mismo en la Biblioteca Universitaria de Leiden ${ }^{4}$.

Lo primero que habría que preguntarse es qué circunstancias tipográficas concretas propiciaron la impresión de dos versiones tan distintas de la Animaduersio montaniana. Hacia abril de 1572 el prototipógrafo real Cristóbal Plantino había imprimido solo 600 juegos completos (de los 1.200 proyectados) de los tres volúmenes del Apparatus sacer, un apéndice integrado por diccionarios, gramáticas, tratados y ediciones de texto como ayuda al estudio y aprovechamiento de la Biblia Regia. Pero para esas fechas ya eran conocidas las reticencias romanas a la Políglota por la inclusión, entre otras, de la versión latina del hebraísta Sanctes Pagninus (revisada por Arias Montano) y la cita de autores sospechosos de judaís-

\footnotetext{
${ }^{1}$ Biblia Sacra Hebraice, Chaldaice, Graece et Latine Philippi II Regis Catholici pietate et studio ad Sacrosanctae Ecclesiae usum (Antuerpiae, 1569-1573). El Museo Plantin-Moretus de Amberes conserva un ejemplar completo de cada una de las versiones: la versión A responde a la signatura A 5; la versión B lleva la signatura B 65.

${ }^{2}$ E. Fernández Tejero, «Benedicti Ariae Montani... De Psalterii Anglicani exemplari animadversio», en N. Fernández Marcos - E. Fernández Tejero, Biblia y humanismo. Textos, talantes y controversias del siglo XVI español (Madrid, 1997), 161-167; EADEM, «Dos tratados de Benito Arias Montano», en Biblia y humanismo, 169-175. El primero de los trabajos vio la luz previamente en A. Dotan (ed.), Proceedings of the Ninth Congress of the International Organization for Masoretic Studies, 1989), ([Atlanta, GA]: Scholars Press for the Society of Biblical Literature and the International Organization for Masoretic Studies, 1992), 43-51.

${ }^{3}$ M. A. Sánchez Manzano, Benito Arias Montano. Prefacios de Benito Arias Montano a la Biblia Regia de Felipe II (León, 2006), CXII-CXXII.

${ }^{4}$ Cf. T. W. Dunkelgrün, The Multiplicity of Scripture: The Confluence of Textual Traditions in the Making of the Antwerp Polyglot Bible (1568-1573) (Ph. D. dissert., University of Chicago, 2012), 296-319.
} 
mo ${ }^{5}$. Se decidió por ello que el editor en jefe de la Biblia, Arias Montano, viajara al Vaticano con la comisión de desvanecer esas sospechas y obtener la aprobación papal a la Biblia plantiniana. En la imprenta de Amberes se dio entonces la orden de detener la impresión del Apparatus durante algunos meses, ya fuera como medida de prudencia a la espera de que se aclarase el turbio panorama de la recepción romana de la Políglota, ya porque el inicio de las revueltas en las provincias de Zeeland y Holanda dejó a Plantino sin papel ni dinero para imprimir lo que faltaba.

Solo cuando llegaron noticias ciertas desde Roma de que la comisión de Arias Montano estaba dando los frutos deseados y, al mismo tiempo, el duque de Alba había tomado de nuevo el control de la situación política en Flandes, a partir de julio de 1572, se comenzaron a imprimir los juegos que faltaban del Apparatus, en un proceso que se extendió hasta agosto de $1573^{6}$. Estas mismas circunstancias explican que existan dos versiones de un número de tratados de los diferentes volúmenes del Apparatus.

En el caso de la De Psalterii Anglicani exemplari animaduersio, Arias Montano aprovechó la oportunidad de una reimpresión para introducir cambios abundantes y significativos entre la primera y la segunda versión de ese texto. Para conocer las causas y las consecuencias de estas variantes, así como para conjeturar la datación de las dos versiones, hay que entrar de lleno en la polémica recepción de la Biblia Políglota de Amberes, que tuvo dos frentes principales: en España fue el teólogo salmantino León de Castro, uno de los principales promotores del encarcelamiento de los hebraístas Fray Luis de León, Gaspar de Grajal y Martín Martínez de Cantalapiedra en 1572, quien persiguió a Arias Montano y su Biblia hasta elevar una denuncia ante el tribunal de la Santa Inquisición. En Flandes, Arias Montano tuvo que lidiar con uno de los más brillantes teólogos de aquel territorio, el obispo de Roermond Wilhelm van der Lindt, alias Lindanus (1525-1588). La polémica entre Arias Montano y Guillermo Lindano llegó a tal grado de obstinación que se extendió hasta

\footnotetext{
${ }^{5}$ Las principales objeciones a la Políglota de Amberes están expuestas en la carta de Juan de Zúñiga, embajador de España en Roma, a Felipe II, con fecha del 4 de febrero de 1572, publicada en T. GonZález CARVAJAL, «Elogio histórico del doctor Benito Arias Montano», en Memorias de la Real Academia de la Historia 7 (Madrid, 1832), 159-160 (doc. 37).

${ }^{6}$ Cf. L. Voet - J. Grisolle, The Plantin Press (1555-1589). A Bibliography of the Works Printed and Published by Christopher Plantin at Antwerp and Leiden, 6 vols. (Amsterdam, Van Hoeve: 1980-1983), 287-288 y 312-315.
} 
la muerte de sus protagonistas. La razón de esta inquina mutua hay que buscarla en una falsa acusación por parte de Arias Montano y una serie de retractaciones no del todo satisfactorias ${ }^{7}$.

El presente artículo tiene un triple objetivo: reunir en un solo estudio, por vez primera, el texto latino y la traducción castellana de las dos versiones de este controvertido texto montaniano; indagar las razones que motivaron la existencia de dos versiones tan distintas de este tratado y analizar los cambios introducidos en la versión B con respecto a la versión A a la luz de la correspondencia privada de Arias Montano y de Lindano; y, finalmente, proponer una datación aproximada para cada una de las dos versiones.

\section{Versión A: casus beLLI ENTRe ARias Montano y Lindano}

\section{1. Edición y traducción anotada}

Ofrezco a continuación la transcripción del texto tal y como aparece en el ejemplar de la versión A que he consultado, conservado en la Biblioteca Nacional de España con signatura R/8904(14), también U 8 (14) ${ }^{8}$ (e1 en el aparato crítico). La versión A de la Animaduersio ha sido editada y traducida al castellano por M. A. Sánchez Manzano en su trabajo Benito Arias Montano. Prefacios de Benito Arias Montano a la Biblia Regia de Felipe II (León, 2006), 262-267 (e2 en el aparato crítico). Resalto en negrita las palabras que fueron modificadas en la segunda versión del texto:

\footnotetext{
${ }^{7}$ De ello me he ocupado ya en trabajos anteriores: cf. A. DÁVILA PéreZ, «La polémica Arias Montano-Wilhelmus Lindanus: Un nuevo documento (AGR I, 115, nr. 3714)», Humanistica Lovaniensia 49 (2000), 139-165; IDEM, «Regnavit a Ligno Deus: Affirmat Arias Montanus; Negat Lindanus. Revisión de la Polémica Benito Arias Montano-Wilhelmus Lindanus a la luz de nuevos documentos», Humanistica Lovaniensia 58 (2009), 125-189; IDEM, «Retractación o pertinacia. Vicisitudes de un tratado parcialmente perdido de Arias Montano al hilo de la polémica en torno a la Biblia Políglota de Amberes», Sefarad 71 (2011), 369-412.

${ }^{8}$ El texto coincide con otros ejemplares de la versión A de la Biblia Regia que he podido consultar: el de la Biblioteca de la Universidad de Granada (BHR/Caja IMP-3-022 (tomo I y siguientes), la Animaduersio se encuentra en el volumen con signatura BHR/ Caja IMP-3-028(12)); y el de la Biblioteca de la Universidad Complutense (BH DER 299 [14] Tomo 8 [14]).
} 


\section{BENEDICTI ARIAE MONTANI DE EXEMPLARI}

\section{PSALTERII ANGLICANI ANIMADVERSIO}

Cum in disciplinarum et scientiae rationibus componendis nihil magis incommodum sit quam ut incerta pro certis habeantur, lectorem admonendum duximus, non omnia, quae aliquando commendantur, manuscripta exemplaria eam fidem mereri, quam ex commendantium auctoritate aestimari oportuerat. Id cum frequenti iam exemplo in aliis libris deprehenderimus in uno Anglicano Psalterio Hebraicis literis manuscripto manifeste indicare possumus, quod id exemplaris correctissi-

10 mi et antiquissimi nomine a doctissimo in nostra aetate scriptore, praecipuae in Ecclesia dignitatis uiro, non a se uisum sed ex alterius relatu summe laudabatur, atque ad grauissimae sententiae a se prolatae testimonium et argumentum citabatur in libro qui $D e$

15 optimo genere interpretandi scripturas inscribitur. Illic enim contendit auctor multa in Bibliis Hebraicis loca esse deprauata et corrupta, Iudaeorum, ut dici solet, malitia; idque adstruit ex fide exemplaris Psalterii, quod magno in pretio haberi in Anglia dicit, idemque Sancti

20 Augustini Archiepiscopi fuisse quondam affirmat, in eoque multa esse correcta, quae in aliis Bibliis corrupta sunt, ut quod «Ierusalem» perpetuo scribatur et non «Ierusalaim», ut in omnibus legitur aliis atque ut uere uocabatur illa ciuitas, sicut a nobis in Geographia est

25 demonstratum.

Deinde unum maximi momenti affert locum ibidem, ut ait, integre conseruatum, in caeteris uero 


\section{ADVERTENCIA DE BENITO ARIAS MONTANO SOBRE EL MANUSCRITO DEL SALTERIO INGLÉS}

Dado que no hay nada más perjudicial al componer los razonamientos de las disciplinas y de la ciencia que el tener lo incierto por cierto, hemos considerado poner al lector sobre aviso de que no todos los ejemplares manuscritos que algunas veces se recomiendan merecen esa confianza que habría convenido prestales en virtud de la autoridad de quienes los recomienda. Esto, puesto que lo hemos descubierto ya con frecuentes ejemplos en otros libros, lo podemos indicar de forma manifiesta en un manuscrito inglés del salterio en letras hebreas que era alabado hasta la saciedad por un doctísimo escritor de nuestra época, hombre de particular dignidad en la Iglesia, como si fuera el ejemplar más antiguo y correcto, sin haberlo visto él mismo, sino siguiendo el relato de otro, y para testimonio y argumento del gravísimo parecer que había expuesto, era citado en un libro que se titula Sobre la mejor manera de interpretar las Escrituras: pues allí sostiene el autor que muchos lugares en la Biblia Hebrea han sido adulterados y corrompidos por la mala intención, según suele decirse, de los judíos, y esto lo prueba basándose en su fe en la copia del salterio que dice que es considerado de gran valor en Inglaterra, y afirma que tal manuscrito perteneció en otro tiempo al arzobispo san Agustín y que en él aparecen correctamente muchas cosas que están corrompidas en otras Biblias, como que siempre se escribe «Ierusalem» y no «Ierusalaim», como se lee en todos los otros; y como de verdad se llamaba aquella ciudad, según hemos demostrado en la Geografía?

A continuación cita un pasaje muy importante conservado allí mismo de forma íntegra, según dice, pero mutilado en los demás, a saber, el

\footnotetext{
${ }^{9}$ Cf. Chanaan siue de duodecim gentibus, tratado montaniano incluido en el tomo VIII de la Políglota, normalmente encuadernado en el quinto lugar. El prefacio lleva fecha del 1 de marzo de 1572. Allí defendía Arias Montano que el nombre correcto hebreo de la Ciudad Santa es «Jerushalaim» y no «Jerusalem»; cf. DunKELGRÜn, The Multiplicity of Scripture, 298-299.
} 
mutilum: is est Psalmi nonagesimi sexti decimus uersus, «Dicite in gentibus, quia Dominus regnauit a

30 ligno»; testatur enim illud «a ligno» in hoc Psalterio esse, quod Iudaeorum malitia olim euulsum inde sit, ut ex Iustino Martyre auctore Graeco ipse aliique citant. Cum uero ad huius sacri Bibliorum operis instructionem nihil non conquirendum nulli difficultati

35 aut tempori aut loco cedendum duxerimus, atque uaria Hebraica, Graeca, Chaldaica et Latina exemplaria, Deo nostros conatus promouente, comportauerimus, nacti etiam sumus illud exemplar Psalterii appellatum Anglicanum, quod tanquam thesaurum magnum 40 diligentissime conseruatum Ioannes Clemens doctissimus et pientissimus uir ex Thomae Mori familia possidet, is enim et optimi exemplaris Pentatheuci Graeci et huius Psalterii nobis copiam fecit. Sed cum Psalterium uideremus, non potuimus

45 non uehementer dolere grauissimo et doctissimo uiro, qui ex aliena fide scripserit et docuerit, sic turpiter esse impositum. Cum primis enim neque liber antiquus est neque ab aliquo qui Hebraicam linguam cognorit scriptus, sed a scriba Latinas eleganter

50 pingendi literas non ignaro, octoginta aut ad summum centum ab hinc annis depictus, breuis liber charactere Hebraico, imitatione magis et pingendi peritia quam legendi notitia relato, adeo corrupte descripto ut uix ullum uerbum integritatem suam retinere uideatur. Habet

55 nonnullorum Psalmorum Latinam interpretationem nostram uulgatam et annotatiunculas illum Iacobi de Valentia stylum redolentes, perbreues illas et raras.

40 Clemens: Clonens e1 55 nonnullorum: nonnulorum e2 
décimo versículo del Salmo nonagésimo sexto ${ }^{10}$ «Dicite in gentibus quia Dominus regnauit a ligno»; pues él declara que la frase «a ligno» se conserva en ese antiguo salterio, frase que debido a la maldad de los judíos fue suprimida hace tiempo a partir de esa época, según citan él mismo y otros a partir del autor griego Justino Mártir. Y puesto que para la preparación del trabajo sagrado de la Biblia nos hemos guiado por el criterio de no dejar nada por investigar, sin ceder ante ninguna dificultad, situación o lugar y, favoreciendo Dios nuestros propósitos, hemos reunido diferentes manuscritos hebreos, griegos, caldeos y latinos, también nosotros hemos dado con ese ejemplar del salterio llamado anglicano, que conservado como un gran tesoro posee el muy docto y piadoso señor Juan Clement, de la familia de Tomás Moro, pues este nos facilitó la consulta tanto del mejor manuscrito del Pentateuco griego como de este salterio ${ }^{11}$. Pero al ver este salterio, no pudimos dejar de lamentarnos profundamente de que se hubiese engañado de manera tan vergonzosa a un importantísimo y doctísimo señor, que escribió y argumentó basándose en la confianza que tenía en otro. Para empezar el libro ni es antiguo ni ha sido escrito por alguien que conozca la lengua hebrea, sino por un escribano que sabía trazar las letras latinas con elegancia, copiado hace ochenta o a lo sumo cien años, un libro breve en carácter hebreo, reproducido más por imitación y pericia de escribir que por conocimiento de leerlo, transcrito tan corruptamente, que apenas alguna palabra parece mantener su integridad. Tiene nuestra traducción latina Vulgata de algunos salmos, y pequeñas anotaciones que, muy breves y escasas, recuerdan el estilo de Jacobo de Valencia.

\footnotetext{
${ }^{10}$ Nonagésimo sexto según la numeración de los Salmos en el texto masorético. En el texto griego de los Setenta y en la Vulgata se corresponde con el Salmo nonagésimo quinto.

${ }^{11}$ La expresión latina «copiam facere», que se lee sin cambios en las versiones A y B, significa «dar acceso» a los manuscritos originales, esto es «facilitar su consulta». Las dos traducciones al castellano de este texto que conozco se dejan arrastrar por la influencia del falso amigo «copiam»: «Pues él nos hizo copia del mejor ejemplar de Pentateuco griego y de este Salterio» (SÁnchez Manzano, Prefacios, 265); «éste nos hizo una copia de un magnífico ejemplar del Pentateuco Griego y de este Salterio» (Fernández Tejero, «Dos tratados de Benito Arias Montano», 174). Teniendo en cuenta que la advertencia de Arias Montano se fundamenta en el examen presencial del manuscrito original del salterio, carece de sentido que lo que Clement proporcionara al equipo de la Políglota fuese una simple copia del mismo.
} 
Cum puerilem omnino rem esse deprehedissem, tamen ad nonagesimum sextum Psalmum me contuli; ibi

60 non modo non reperi illud testimonium, «a ligno», uerum totum illum dimidium uersum desideraui, uidelicet, «Dicite in gentibus quia Dominus regnauit». Et tamen in toto libro quanquam plura uerba et integrae sententiae desiderentur, | nihil tamen deest quod scriptum antea

65 fuerit. Constat enim integra et continuata scriptura, eaque, ut diximus, paene recens, puncti et uocalis ex minio accentus ex Heliotropio depicti, capitales literae aliquot in initiis Psalmorum aureae, sed quae Latinam magis quam Hebraicam referant formam: luderene an illude-

70 re scriba ille uoluerit, satis dignoscere non poteram.

Quod ad antiquitatem attinet, sciunt pictores quantam aetatem Heliotropii color ferre ualeat, rarissime enim centesimum attingit annum. Vt autem antiquorum ac diligenter scriptorum exemplarium fidem sanctam, ita

75 huiusmodi nullam esse oportuit, etiam si mille essent reperta et lecta, nedum unius nunquam uisi ab eo, qui summam auctoritatem affirmare contendebat. Quod Sancto Augustino adscribatur, sic res habet. In prioribus membranis uacuis sunt uoculae quaedam

80 scriptae, eo modo quo scribere solemus, cum calamum temperantes experimur, sed a scriptore pingendi literas rudissimo, inter alia uerba illa ter aut quarter sunt: «Hic liber, hic liber est, hic liber est Sancti Augustini»; atque ille quisquis fuit scriptor, uel alius, 85 cultello abrasit «ncti Augustini». Ita tamen ut obiecta luci membrana lectionem integram prodat, namque atramentum tenacius haeserat, quam ut abradere

61 desideraui: desiderari e2 63 plura om. e2 66 paene: pene $\mathbf{2}$ 68 aureae: aurea e2 69 luderene: ludere ne e1 
Al haberme dado cuenta de que el asunto era completamente pueril, finalmente me fui al salmo nonagésimo sexto; allí no solo no encontré aquel testimonio «a ligno», sino que faltaba todo aquel medio versículo, es decir, «Dicite in gentibus quia Dominus regnauit». Y, no obstante, aunque en todo el libro se echan de menos muchas palabras y frases enteras, nada falta no obstante que no hubiera sido escrito antes, pues es evidente que la escritura es íntegra y continua, y esta, como dijimos, más o menos reciente, los puntos y los acentos anaranjados de la vocal están pintados a partir del heliotropio ${ }^{12}$, algunas letras mayúsculas en los comienzos de los salmos son doradas, pero se asemejan más a la forma latina que a la hebrea: si aquel escribano quiso jugar o divertirse, no había podido dilucidarlo bien.

En lo que respecta a la antigüedad, saben los pintores cuánta edad puede conllevar el color de heliotropio, pues muy raramente llega a cien años ${ }^{13}$. Pero de la misma manera que es sagrada la fidelidad de los manuscritos antiguos y escrupulosamente escritos, así también convino que no prestásemos ninguna a un manuscrito de este tipo, por mucho que se hubiesen encontrado y leído mil, menos aun a un solo manuscrito nunca visto por aquel que se esforzaba por afirmar la máxima autoridad para tal manuscrito. En cuanto al hecho de que se asigne a san Agustín, así está la cosa. En los primeros pergaminos en blanco hay ciertas palabritas escritas, del mismo modo en que solemos escribir cuando probamos al cortar la pluma ${ }^{14}$, pero por un escritor muy rudo al trazar las letras; entre otras palabras están tres o cuatro veces: «Este libro, este libro es, este libro es de san Agustín». Y

${ }^{12}$ Sustancia de color púrpura tomada de estas flores.

${ }^{13}$ Arias Montano no aporta fuente alguna para esta afirmación, que también se puede leer en la versión B de la Animaduersio. En todo caso la evidencia técnica presentada por el supervisor de la Políglota no parece ser cierta, pues el manuscrito, de hecho, en época de Arias Montano tenía aproximadamente cuatrocientos años. Cf. DunKELGRÜN, The Multiplicity of Scripture, 311-312.

${ }^{14} \mathrm{La}$ expresión «calamum temperare», que aparece en las dos versiones del texto, ha generado alguna dificultad a los traductores del mismo. SÁnchez MANZANo interpreta 'cuando probamos cogiendo la pluma' (Prefacios, 267), mientras que Fernández TeJero traduce 'cuando hacemos pruebas templando el cálamo' («Dos tratados de Benito Arias Montano», 175). La expresión es recogida en los diccionarios bilingües latín-español de la época con el significado de 'cortar la pluma', paso previo a su uso para la escritura. Cf. Thesaurus hispano-latinus utriusque linguae uerbis et phrasibus abundans, primum a $P$. Bartholomaeo Brauo e Societate Iesu inuentus [...] (Barcelona, 1791), 326. 
ille uoluerit uel potuerit. Hinc scilicet aestimatio et auctoritas libro facta est ab iis qui Hebraice omnino

90 ignorauerint: clare enim legitur: «Hic liber est Sa»; reliqua ad lucem in rasa membrana leguntur. Haec est antiquitas et maiestas. Est deinde alius uersiculus huic subiunctus, qui et scriptoris testimonium et eius scripturam commendat «Hic liber est Sa.»

95 sed littera nescio qua. Porro idem liber, ut ille habet, multis hic Antuerpiae doctis et Hebraicarum literarum peritis ostensus est (interim dum apud nos per octo menses integros mansit) Christophoro Plantino, qui illum ad nos deferri curauit, Francisco Raphelingio

100 Plantini genero, Guidoni Fabritio eiusque fratri, Ioanni Harlemio, Ioanni Goropio Becano, Aluaro Nonio, doctoribus et aliis compluribus, redditus est a nobis Clementi ad quem pertinebat; isque illum in sua bibliotheca Mechliniae habet: certior a nobis

105 factus quid thesauri in eo contineatur. Vt uero totius rei breue specimen praeberemus, quod satis esset ad caetera cognoscenda, eum ipsum nonagesimum sextum Psalmum fidelissime ad illam fidem descriptum, huic nostra animaduersioni adprimendum curauimus. 
quien quiera que fuese el escritor u otro borró raspándolo «an Agustín», de modo que, no obstante, el papel puesto al trasluz revela todo el texto, pues la tinta se había adherido más fuerte de lo que él quiso o pudo raspar. De ahí viene, evidentemente, que hayan estimado y concedido autoridad al libro quienes han ignorado por completo el hebreo, pues claramente se lee «Este libro es de s.». El resto se lee a la luz en el pergamino raspado. Esta es la antigüedad y la majestad. A continuación hay otro versículo colocado debajo de este que ensalza el testimonio del escritor y su escritura «Este libro es de san., pero no sé con qué letra» ${ }^{15}$. En su momento el mismo libro, tal y como está, aquí en Amberes fue mostrado a muchos doctos y expertos en las letras hebreas (mientras que permaneció en nuestro poder durante ocho meses enteros), a Cristóbal Plantino, quien se encargó de que se nos enviara el manuscrito, a Francisco Rafelengio yerno de Plantino, a los doctores Guy Lefèvre y su hermano, a Juan Harlemio, a Juan Goropio Becano, a Álvaro Núñez y a otros muchos, y fue devuelto por nosotros a Clemente, a quien pertenecía; y él lo tiene en su biblioteca de Malinas, tras conocer por nosotros qué tesoro se encerraba en él ${ }^{16}$. Pero para proporcionar una breve muestra de toda la cuestión, lo que será suficiente para conocer el resto, ese mismo salmo nonagésimo sexto copiado con la mayor fidelidad según el original nos hemos encargado de que se imprima junto a esta advertencia nuestra ${ }^{17}$.

\footnotetext{
${ }^{15}$ Para comprender este párrafo sobre la atribución del manuscrito a san Agustín hay que conocer la historia de este interesante códice. El manuscrito nunca perteneció a san Agustín de Canterbury, el primer evangelizador de las Islas Británicas, sino a la biblioteca de la Abadía de san Agustín, en cuyo catálogo de 1497 figura dicho códice. Alguno de los muchos poseedores posteriores de ese manuscrito raspó el pergamino para borrar el ex libris de la Abadía de san Agustín, aunque mirado al trasluz se podía leer en tiempos de Arias Montano, y aun hoy en día, la antigua asignación del códice. Todos estos datos acerca de la historia del manuscrito, sobre la que volveremos más adelante, proceden del estudioso que ha localizado en la Biblioteca Universitaria de Leiden el mismo manuscrito hebreo de salterio que generó esta controversia: DUNKELGRÜN, The Multiplicity of Scripture, 307.

${ }^{16}$ El tono irónico de Arias Montano es evidente. Tras la revisión del manuscrito los integrantes del equipo de la Políglota comunicaron a Clement que, en su opinión, el manuscrito del salterio de su propiedad ni era antiguo ni demasiado valioso.

${ }^{17}$ Al pie de la Animaduersio, el lector encuentra el Salmo 95 (96) impreso tal y como aparece en el manuscrito hebreo del salterio alabado por Lindano. Al final de este apartado reproducimos en las dos páginas que siguen el texto de la primera versión de la Animaduersio tal y como se imprimó en la Biblia Políglota.
} 


\section{2. Comentario}

La redacción inicial de la Animaduersio o 'Advertencia' tomó la forma de una reseña hiriente, en son de guerra, del tratado escrito por Lindano titulado De optimo scripturas interpretandi genere libri III siue undenam solida Scripturarum Sacrarum ueritas sensusque germanus ac uerus nunc temporis sit petendus: an ex Hebraica, quam dicunt, ueritate, num fontibus Graecis hauriendus an Vulgata potius editione Latina quaerendus uti in Concilio Tridentino dudum definiebatur (Coloniae, apud Maternum Cholinum, 1558) ${ }^{18}$. En dicha obra el obispo neerlandés expuso que aunque la Vulgata necesitaba ser corregida, dicha traducción estaba basada en un texto, perdido ya en el siglo XVI, mucho mejor que los manuscritos hebreos y griegos conservados por entonces. Con esta tesis se sumó Lindano a la corriente biblista que denostaba el original hebreo de las Sagradas Escrituras en la idea de que había sido corrompido por los judíos. Y como prueba de ello elogiaba un manuscrito hebreo del salterio, procedente de Inglaterra, que conservaba por completo ciertas palabras y pasajes completos (también presentes en la Septuaginta y la Vulgata), que habían sido omitidos en todos los ejemplares del salterio hebreo de su época.

El tratado de Lindano había suscitado gran polémica desde el momento en que se publicó por su abierto rechazo a la primacía del original hebreo para el estudio de la Biblia ${ }^{19}$. En 1559 Juan Isaac Levita, profesor de hebreo en la Universidad de Colonia, se lanzó contra Lindano en su Defensio ueritatis hebraicae Sacrarum Scripturarum aduersus libros tres reuerendi D[omini] Wilhelmi Lindani quos De optimo Scripturas interpretandi genere inscripsit. Según el testimonio de Lindano, Isaac, compatriota suyo y

\footnotetext{
${ }^{18} \mathrm{H}$. de Vocht considera esta edición una reimpresión de la que pudo ser una editio princeps de 1552 ó 1553, aparecida en Lovaina, a la vista de una alusión a ella en una carta de Pedro Canisio, antiguo estudiante de Lovaina, a Lindano, quien todavía vivía en Dillingen. Es decir, la obra sería anterior a 1557; cf. H. De Vocht, History of the Foundation and the Rise of the Collegium Trilingue Louaniense, 1517-1550 [= Humanistica Lovaniensia 10-13], 4 vols. (Louvain, 1951-1955), IV, 305. La traducción al castellano del título de la obra de Lindano es la siguiente: 'Tres libros sobre el mejor género de interpretar las escrituras o de dónde se ha de buscar en esta época la sólida verdad y el sentido auténtico y verdadero de las Sagradas Escrituras, si se ha de beber de la que llaman verdad hebraica o de las fuentes griegas o mejor se ha de buscar de la edición Vulgata como se determinaba hace tiempo en el Concilio de Trento'.

${ }^{19}$ Cf. De Vocht, Collegium Trilingue Louaniense, IV, 383-389.
} 
también protegido (le había socorrido a él y a toda su familia en Lovaina poco después de convertirse del judaísmo al cristianismo) se vio obligado a retractarse en varias ocasiones y a remitirle una carta de arrepentimiento por haber difamado su nombre ante la amenaza de Lindano de publicar un escrito anti-rabínico en defensa de la Vulgata ${ }^{20}$. Entre el 10 de noviembre de 1563 y el 21 de octubre de 1564 Juan Isaac realizó una estancia en la imprenta de Cristóbal Plantino, dedicado a la revisión del Thesaurus Linguae Sanctae de Sanctes Pagnino. En su polémica con Lindano, el profesor de Colonia había recibido el apoyo explícito de jesuitas como Pedro Canisio y, especialmente, Juan Harlemio, quien más tarde se convirtió en uno de los grandes colaboradores de la Biblia Regia y en el teólogo lovaniense más próximo a Arias Montano. Esta cadena de acontecimientos previos apunta a que, en realidad, la Animaduersio de Arias Montano recogía la oposición a las tesis de Lindano que Juan Isaac había enarbolado años antes y transmitido al entorno de la casa tipográfica de Cristóbal Plantino.

Arias Montano no ocultó esta deuda, como prueba su carta dirigida al monje cartujo Esteban de Salazar el 4 de febrero de 1594, un documento clave para el tema que nos ocupa porque el biblista resume ab ouo usque ad mala -aunque de manera muy parcial- su controversia con Lindano ${ }^{21}$ : en este documento Arias Montano expone que la obra de Lindano se debe leer al mismo tiempo que la de un doctor catedrático de Colonia (a saber, Juan Isaac) para comprender el alcance de la polémica recepción de la Animaduersio. Theodor Dunkelgrün ha demostrado que Arias Montano se sirvió en su advertencia publicada en la Políglota de algunos de los argumentos empleados por Juan Isaac en su refutación de la tesis de Lindano publicada trece años atrás ${ }^{22}$.

Pero volvamos al texto impreso en el último tomo de la Políglota. Después de haber defendido la integridad de la transmisión del original bíblico hebreo en el prefacio precedente titulado De uaria in Hebraicis libris lectione ac de Mazzoreth ratione atque usu, Arias Montano añade una

\footnotetext{
${ }^{20}$ Véase sobre este particular la carta de Lindano a Arias Montano del 10 de abril de 1573, conservada en el manuscrito de la Biblioteca Real de Estocolmo A 902, fols. 57-60 y publicada por B. Macías Rosendo, La Biblia Políglota de Amberes en la correspondencia de Benito Arias Montano (Ms. Estoc. A 902) (Huelva, 1998), 304-305.

${ }^{21}$ Carta publicada por GonZález CARvajal, «Elogio histórico», 188-193.

${ }^{22}$ Cf. Dunkelgrün, The Multiplicity of Scripture, 315-318.
} 
nota que tiene como objetivo advertir al lector de que no todos los manuscritos apreciados por los biblistas de su época tienen el mismo valor; y, como ejemplo, se centra en el manuscrito hebreo ensalzado por Lindano, cuyo nombre no cita en ningún lugar del texto, aunque sí el título de su tratado De optimo interpretandi scripturas genere, obra y autor de sobras conocidos en gran parte de Europa por el interés despertado tras la polémica con Juan Isaac. Tras un examen filológico inicial, Arias Montano dictamina que el manuscrito elogiado por Lindano ni era antiguo ni fue escrito por alguien que dominara el hebreo: así, por ejemplo, muy pocas palabras estaban correctamente escritas y algunos caracteres y signos de puntuación se parecían más a los latinos que a los hebreos.

A estas pruebas periciales Arias Montano añade la siguiente denuncia: Lindano había afirmado que dicho manuscrito hebreo del salterio conservaba íntegro el versículo 10 del Salmo 95 (96) («Dicite in gentibus quia dominus regnauit a ligno»), cuando Arias Montano y su equipo de colaboradores pudieron comprobar con sus propios ojos que tal pasaje también faltaba en aquel manuscrito del salterio alabado por Lindano («Deinde unum maximi momenti affert locum ibidem, ut ait, integre conseruatum, in caeteris uero mutilum: is est, Psalmi nonagesimi sexti decimus uersus, Dicite in gentibus, quia Dominus regnauit a ligno; testatur enim illud a ligno in hoc Psalterio esse [...] tamen ad nonagesimum sextum Psalmum me contuli; ibi non modo non reperi illud testimonium, a ligno, uerum totum illum dimidium uersum desideraui, uidelicet, Dicite in gentibus quia Dominus regnauit»). Todas estas pruebas conducen a Arias Montano a sugerir que el autor del tratado De optimo scripturas interpretandi genere se había dejado guiar por el parecer de otros, que no había visto con sus propios ojos el manuscrito hebreo que alababa («non a se uisum sed ex alterius relatu summe laudabatur», «qui ex aliena fide scripserit et docuerit»). Puede que Arias Montano afirmase que el obispo neerlandés no había visto el manuscrito más para excusarlo que para ofenderlo, pero lo cierto es que Lindano tomó como una grave ofensa el que se le presentara ante el mundo como un teólogo que escribía de oídas.

En el conjunto de su argumentación Arias Montano concede especial peso a la prueba de que Lindano había afirmado que el sintagma «a ligno» se podía leer en el manuscrito hebreo del salterio procedente de Inglaterra. En efecto, no solo se refiere a este error en el centro de su escrito como 
prueba de cargo en medio de otras consideraciones técnicas sobre el hebreo del referido manuscrito, sino que incluso al final de la Animaduersio se imprime el salmo 95 (96) tal y como se podía leer en el manuscrito hebreo alabado por Lindano, para que el lector pudiese comprobar que Lindano no estaba en lo cierto al afirmar -presuntamente- que el sintagma «a ligno» se encontraba en dicho manuscrito. Esta efectista denuncia, colocada en el lugar más visible de su Animaduersio, debía suponer el jaque mate («quod satis esset ad caetera cognoscenda») al libro y al proceder filológico de Lindano, así como al planteamiento general de todos los detractores de la lengua hebrea y del uso del original hebreo para el estudio del Antiguo Testamento. Después de todo, la Biblia Políglota de Amberes, en la que participaron ilustres hebraístas, necesitaba refutar los planteamientos de quienes se oponían a los presupuestos metodológicos en los que se basó esa colosal edición del texto sagrado.

En trabajos anteriores ${ }^{23}$ he descendido a los textos de la polémica para comprobar si en algún lugar de su citado libro Lindano había afirmado que el versículo 10 del salmo 95 (96) («Dicite in gentibus quia dominus regnauit a ligno») se conservaba íntegramente en el manuscrito del salterio que alababa. Revisemos aquí de nuevo los pasajes concretos que dieron lugar a la denuncia de la Animaduersio montaniana.

En el folio $19 \mathrm{v}$ de su De optimo scripturas interpretandi genere (libro primero, tercer capítulo titulado Hebraicam lectionem hodiernam non esse germanam et genuinam sed adulteratam) Lindano cita una frase del salmo 13, versículo tercero («sepulchrum guturosa patens est eorum», 'su garganta es un sepulcro abierto') que se echaba en falta en todas las biblias hebreas impresas de su tiempo, pero de la que san Pablo daba testimonio en su carta a los romanos ${ }^{24}$. Además Lindano declara haber consultado un manuscrito hebreo del salterio, que él creía que perteneció a san Agustín, obispo de Canterbury († ca. 604), donde se conservaba de forma íntegra ese pasaje, de donde se deducía también la antigüedad y el valor de dicho manuscrito. Todo ello probaba, por lo menos según Lin-

${ }^{23}$ DÁvila Pérez, «Regnavit a Ligno Deus: Affirmat Arias Montanus; Negat Lindanus»,128-130; IDEM, «Retractación o pertinacia», 383-387.

${ }^{24}$ VvLG. Rom., 3,13. El tercer versículo del salmo 13 (14) «sepulchrum guturosa patens est eorum» falta en la edición de la Vulgata que vio la luz en las políglotas de Alcalá y de Amberes. 
dano, que este pasaje figuraba en los más antiguos manuscritos hebreos y que había sido suprimido posteriormente por los judíos, en un ejemplo más de la corrupción y adulteración del original hebreo del texto bíblico ${ }^{25}$.

Un poco más adelante, entre los folios $27 \mathrm{v}$ y $28 \mathrm{r}$ del capítulo $\mathrm{V}$, titulado Deesse et iustas quasdam Hebraeorum codicibus sententias, también en el libro primero de su tratado De optimo scripturas interpretandi genere, Lindano da por demostrada la idea de que los manuscritos en los que se basa la llamada verdad hebraica de su tiempo han sufrido la pérdida no solo de letras o pequeñas palabras, sino también de frases enteras. Como prueba palmaria vuelve a citar aquí, como ya hizo en el capítulo tercero, el salmo 13, cuyo versículo tercero se ha restituido en hebreo a partir del manuscrito inglés del salterio, mientras que faltaba en todos los impresos de su época.

Nicolaus ille S. Damasi diaconus, ante annos circiter 400, aetate Lucii Secundi, anno Domini 1150, si Bessarioni credimus, peritissimus, Vaticanae Bibliothecae, ut idem ait, Suffraganeus, de Sacrae Scripturae, ad Petrum S. Petri Canonicum, emendatione, scribit se nonnulla comperisse, teste Cardinale Bessarione, de Hebraeo abesse, quae tamen in omnibus latinis codicibus pariformiter reperiantur, quod exemplis comprobat liquidis: quae utinam a Bessarione praeter illud, Exeamus in agrum, Ge. 4 non fuissent silentio praetermissa. Istius rei fidem sane perspicuam faciat uel unus ille locus dudum ex Psalm. 13 commemoratus, atque Hebraice antiquissimo ex codice Anglicano restitutus, cap. 3 qui in omnibus istis impressis libris, unde Hebraicam metiendam uolunt ueritatem, desideratur.

Inmediatamente después de esta referencia al manuscrito del salterio hebreo, Lindano concluye el capítulo $\mathrm{V}$ con un párrafo final dedicado a la Septuaginta: allí se pueden encontrar -escribe el autor- muchos

\footnotetext{
${ }^{25}$ «Quod enim 70 reddiderunt Psal. 13, uidelicet, Sepulchrum patens est guttur eorum et quae uersibus compluribus sunt annexa, apud Hebraeos in omnibus hodie impressis desideratur: quod autem olim in Hebraicis lectum fuerit codicibus, unus D[iuus] Paulus locum hunc integrum ad Romanos et Iudaeos Romanenses scribens, contestatur. Imo et hisce oculis uidi ipse meis uetustissimum quodam Psalterii exemplar Hebraicum, quod D[iui] Augustini Episcopi illius Cantuariensis, qui Angliam a Pelagianismo repurgauit ante annos circiter 950 fuisse creditur, et obscurissima ob antiquitatem loquitur inscriptio, ubi locus iste in contextu hunc in modum legitur totus atque integer»; Lindano, De optimo scripturas interpretandi genere, 19-20.
} 
pasajes que no se conservan en los manuscritos hebreos de su época: un caso bien conocido podría servir como ejemplo, el del salmo 95 (96) «Regnauit a ligno», en el que Justino Mártir (y no Lindano) acusó a los judíos en su Diálogo con el judio Trifón ${ }^{26}$ de haber suprimido el sintagma «a ligno»:

Quinetiam in illa nunquam satis laudata 70 editione reperiuntur plurima quae in codicibus hodie non extant Hebraicis: sed unum ex omnibus suffecerit prompsisse illustrius.

Nobilem illam de Messia crucifigendo et a ligno paganis regnaturo Iudaei, teste D. Iustino, Dialo. In Triphone Archisynagogo Ephesio, fol. 83, mutilarunt. Nam cum eo hac de re disputans subterfugientem hoc Psal. 95 capitulo, Regnauit a ligno, conuincit, illud $\tau$ ò

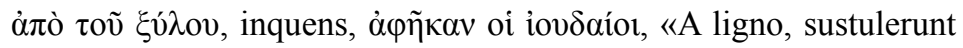
Iudaei» ${ }^{27}$. Quod cum tota Triphonis cohors suo agnoscat silentio (plagium adeo nefarium atque sacrilegum haud dubie negatura, ni luce fuisset clarius meridiana) non est cur diffusius Iudaeos furti adeo sacrilegi arguamus, legisque Cornelia peragamus $\operatorname{reos}^{28}$.

En conclusión, era otro versículo, el tercero del Salmo 13 («sepulchrum gutturosa patens est eorum») el que, según Lindano, se conservaba en el salterio hebreo procedente de Inglaterra y se había perdido en las copias impresas del salterio hebreo de su tiempo. Solo al final del capítulo cinco, cuando se llega al apartado de conclusiones sobre la pérdida de palabras y frases completas en los manuscritos hebreos, Lindano cita efectivamente el conocido versículo 10 del Salmo 95 (96), pero se refiere a este para valorar la Septuaginta («Quinetiam in illa nunquam satis laudata 70 editione reperiunur plurima [...]»), como un caso archiconocido desde san Justino Mártir de la pretendida

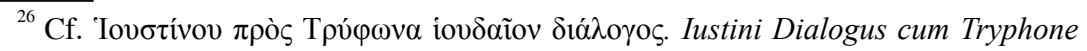
iudaeo, en J. P. Migne (ed.), Patrologia Graeca, VI (Paris, 1857), cols. 471-800.

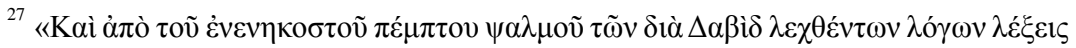

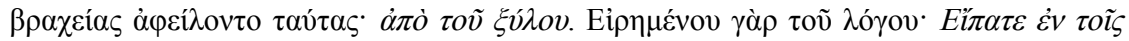

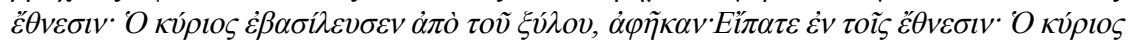
$\dot{\varepsilon} \beta \alpha \sigma i ́ \lambda \varepsilon v \sigma \varepsilon v \gg ;$ en Migne (ed.), Patrologia Graeca, VI, cols. 645-646, cap. LXXIII; y M. Marcovich (ed.), Iustini Martyris Dialogus cum Tryphone (Berlin-New York: De Gruyter, 1997), 195.

${ }^{28}$ LindANO, De optimo scripturas interpretandi genere, 27-28.
} 
corrupción del texto bíblico por los judíos ${ }^{29}$. Lindano sabía de sobras que la expresión «a ligno» no se encontraba en el salterio hebreo que elogiaba, que era antiguo pero ya corrupto, como en su opinión demostraba, precisamente, el hecho de que no contuviera la expresión que, según la denuncia de san Justino Mártir, había sido suprimida malévolamente por los judíos.

¿Cómo podemos entonces explicar la acusación contenida en la Animaduersio de Arias Montano? Posiblemente el biblista español, o quizás alguno de sus colaboradores, leyó de manera un tanto precipitada los dos párrafos finales del capítulo $\mathrm{V}$ del libro de Lindano $\mathrm{y}$, al no percatarse de que el párrafo que empezaba por «Quinetiam [...]»se refería a la Biblia de los Setenta, conectó erróneamente el ejemplo de «regnauit a ligno», que se refería precisamente a la Septuaginta, con el manuscrito del salterio citado en el párrafo anterior, deduciendo de ahí que Lindano afirmaba que el versículo completo del salmo 95 (96) también se encontraba en el manuscrito hebreo del salterio, deducción a todas luces errónea. Si al redactar la Animaduersio Arias Montano tenía delante el libro de Lindano o citaba de memoria es una cuestión difícil de dilucidar. El problema es que el supervisor de la Políglota parece que no hizo una relectura cuidadosa del texto y extrajo de una primera lectura apresurada el principal argumento de su Animaduersio contra el proceder científico de Lindano. Hay errores que tienen una mayor repercusión que otros: el de Montano en su escrito contra Lindano le perseguiría durante toda su vida.

\footnotetext{
${ }^{29}$ Efectivamente, la controversia sobre la presunta supresión por los judíos del sintagma «a ligno» viene desde el siglo II d. C. El texto de la Vulgata no incluye el sintagma que san Justino denuncia en su diálogo que ha sido suprimido intencionadamente, y las

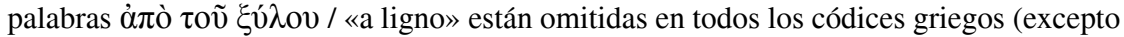
el Codex Veronensis de san Justino), en los Hexapla de Orígenes, en los comentarios de san Jerónimo y en la mayoría de las versiones latinas. Por el contrario, el sintagma sí se incluye en la Vetus Latina y es citado también por Tertuliano (cf. E. Evans [ed.] Tertullian. Adversus Marcionem [Oxford, 1972], lib. III, cap. XIX, pág. 226) y otros padres de la Iglesia como Lactancio, Cipriano, Ambrosio, Casiodoro, que pudieron haberlo leído en algunas copias de la Septuaginta de su tiempo. Por último, la Iglesia Católica conservó en el oficio divino las palabras «a ligno», que también pueden leerse en el himno Vexilla regis prodeunt de Fortunato (siglo VI).
} 


\section{3. Datación}

No sería arriesgado defender que la versión A de la Animaduersio debió de ser escrita hacia el 13 de enero de 1572, la misma fecha en la que Montano data el prefacio titulado De uaria in Hebraicis libris lectione ac de Mazzoreth ratione atque usu, al que se añade, a modo de apostilla, el escrito objeto de este estudio. En todo caso, se puede fijar varios términos post quem non para la versión A: el primero es el mes de abril, cuando se detuvo la impresión del primer juego de tomos del Apparatus Sacer por las razones expuestas más arriba; otro punto más concreto fue el 26 de abril, fecha en la que Montano ya había partido hacia Roma para tratar de conseguir la aprobación papal de la Políglota $^{30}$; la tercera referencia es la fecha de la muerte de Juan Clement, el bibliófilo que prestó el manuscrito del salterio al equipo de Montano, quien a su vez se lo devolvió tras ocho meses: Juan Clement falleció el 1 de julio de 1572, hecho que aún no había acontecido cuando se redactó la versión A, pero del que sí se da noticias en la versión $\mathrm{B}^{31}$.

En conclusión, la versión A de la Animaduersio se imprimió en la primera mitad de 1572, antes, en todo caso, del 1 de julio de 1572 , fe-

${ }^{30}$ Cf. carta de Cristóbal Plantino a Arias Montano escrita entre el 13 y el 20 de mayo de 1572, en A. Dávila Pérez, Benito Arias Montano. Correspondencia conservada en el Museo Plantin-Moretus de Amberes (Alcañiz-Madrid: Instituto de Estudios Humanísticos, Editorial Laberinto, CSIC, 2002), números [72 05 13-72 05 20], pág. 55.

${ }^{31}$ Juan Clement $(\dagger 1$ de julio de 1572) es citado en una carta inédita conservada en Simancas, con fecha del 13 de febrero de 1570, donde Arias Montano explica los criterios y los listados para distribuir la ayuda económica española entre los ingleses católicos residentes en los Países Bajos; en la categoría de nobles laicos con familia se puede leer el nombre doctor Clement, como cabeza de una familia de cuatro miembros (cf. Archivo General de Simancas, Estado, 583/17-18bis). Médico procedente de Yorkshire, pronto entró al servicio de Tomás Moro, que le hizo preceptor de sus hijos; en 1526 Clement contrajo matrimonio con Margaret, hija adoptiva de Moro. En 1549 tuvo que exiliarse en los Países Bajos huyendo de la represión de los católicos en su país natal. Tras un paréntesis de los años 1554-1560, en los que pudo regresar a Inglaterra, volvió a Bélgica, estableciendo su residencia definitiva en Malinas. Poseyó una importante biblioteca y colección de manuscritos griegos y latinos y fue autor de traducciones del griego al latín de varias obras religiosas. Sobre Clement puede consultarse la siguiente bibliografía: A. W. ReED, «John Clement and his Books», The Library, Fourth Series 6 (1926), 329-339; G. Mercati, «Sopra Giovanni Clement e i suoi manoscritti», La Bibliofilia 28 (1926), 8199; P. Wallis, «Clement, John (d. 1572)», en Oxford Dictionary of National Biography (publicado en línea en septiembre de 2004). 
cha de la muerte de Clement; seguramente antes también de la salida de Arias Montano de Amberes en dirección a Roma, a finales de abril; y muy probablemente en las mismas fechas (entre enero y marzo) en las que se publicó el prefacio De uaria in Hebraicis libris lectione ac de Mazzoreth ratione atque usu, escrito el 13 de enero de 1572, al pie del cual se imprimió la Animaduersio.

\section{REACCIÓN DE LINDANO Y NEGOCIACIONES PARA UNA RETRACTACIÓN IMPRESA (VERSIÓN B)}

En vista de todo lo anterior, Lindano llevaba razón al afirmar que Arias Montano había atacado con una falsa acusación su nombre en la edición más ambiciosa de la Biblia del siglo XVI. En mi opinión, Montano no tenía intención de acusar a Lindano de falsario por haber afirmado algo que no era cierto; creo más bien que pretendía presentarlo como un estudioso que se había dejado guiar por la opinión de otros. Los escasos conocimientos de hebreo que tenía Lindano hacían a Montano sospechar que esto podía haber ocurrido así. Pero la redacción final de la versión A de la Animaduersio, hiriente y agresiva, abría la posibilidad de que la comunidad científica interpretara que Lindano, más que dejarse llevar por la opinión de terceros, había mentido al afirmar que el sintagma «a ligno» se encontraba en el manuscrito hebreo del salterio. En una época en que los autores desarrollaron una preocupación obsesiva por alcanzar la fama literaria y defenderla de posibles calumniadores, nada tiene de extraño que este episodio fuera el detonante de una polémica de muy largo recorrido y jalonada por variopintos episodios de encuentros, desencuentros, retractaciones a medias y, sobre todo, de lucha titánica para preservar el propio buen nombre.

Arias Montano no regresa a Amberes de su comisión romana hasta el 18 de diciembre de 1572. En su ausencia, durante el otoño de ese mismo año, se producen ya los primeros movimientos de Lindano. En este punto se hace necesario ir contrastando el testimonio de los hechos que ofrece cada uno de los protagonistas de la polémica en la documentación conservada. Montano relata de la siguiente manera los acontecimientos en su citada carta de 1594, donde expone, de forma muy parcial, como se ha apuntado ya, un amplio resumen de su controversia con Lindano:

SEFARAD, vol. 74:1, enero-junio 2014, págs. 185-254. ISSN: 0037-0894. doi:10.3989/sefarad.014.006 


\section{BENEDICTI ARIÆ MONTANI DE EXEMPLARI PSALTERII ANGLICANI ANIMADVERSIO.}

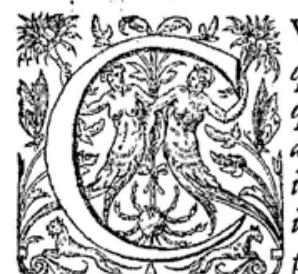

$\mathrm{V}_{\mathrm{M}}$ in difciplinarum $\mathrm{F}^{\mathrm{f}}$ cientie rationibus componendis nibil magis incommodum fit, quàm vt incerta pro certis babeantur, lectorem admonendum duximus, non omnia, que aliquando commendantur, manuscripta exemplaria eam fidem mereri, quam ex commendantium auc7oritate eftimari oportuerat. id cùm frequenti iam exemplo in alijs libris deprebenderimus, in pno Anglicano P falterio Hebraicis literis manufcripto manifestè indicare pofjumus, quod id exemplaris correctißimi et antiqui ßimi nomine à doctißimo in nostra atate fcriptore, praciG ad grauiffime fententic à fe prolate, teftimonium os argumentum citabatur in libro qui De optimo genere interpretandi fripturas in cribitur: illic enim contendit aubtor, multa in Bibliis Hebraicis toca effe deprauata of corrupta, Iudsorum, bt dici folet, malitia, idque adfruit ex fide exemplaris $P$ Jalterï, quod magno in pretio baberi in Anglia dicit, idemque fancti Augustini Archiepifcopi fuiffe quondam affirmat, in eóque multa effe correcta, quie in aliis Bibliis corrupta funt; $v t$ quòd Ierufalem perpetuò fcribatur, \& non Ierufalaim, $v t$ in omnibus legitur aliis: atque vt pere pocabatur illa ciuitas, ficut à nobis in Geograpbia est demonstratü. Deinde vnum maximi mos menti affert locü, ibidem, vt ait, integrè conferuatum, in cateris verò mutilum; is est PJalmi nonagefimi fexti decimus perfus, Dicite in gentibus, quia Dominus regnauit à ligno; teftatur enim illud, à ligno, in boc P Jalterio effe, quod Indarou malitia olim euulfum inde fit, vt ex Iuftino Martyre auctore Greco ipfe alìqque citant. Cùm verò ad buius facri Bibliorum operis inftructionem nibil non conquirendum nulli difficultati, aut tempori, aut loco cedendum duxerimus, atque varia Hebraica, Graca, Chaldaica, er Latina exemplaria, Deo noftros conatus promonente, comportauerimus; nacti etiam fumus illud exemplar P falterij appellatum Anglicanum, quod tanquam the faurum magnum diligentiffimè conferuatum Ioannes Clonens doctiffimus \& pientifimus vir exThome Morifamilia poßsidet, is enim

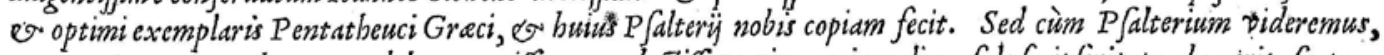
non potuimus non vebementer dolere, grauiffimo \&o doctiffimo viro, qui ex aliena fide fcrip ferit es docuerit, fic turpiter effe impofitum. Cùm primis enim neque liber antiquus est, neque ab aliquo, qui Hebraicam linguan cognorit, fcriptus, fed à fcriba Latinas eleganter pingendiliteras non ignaro, octoginta, aut ad fummum centum ab binc annis depictus, breuis liber charactere Hebraico, imitatione magis do pingendi peritia quàm legendi notitia relato, adè corruptè defcripto, vt vix vllum verbum integritatern fuam retinere videatur. babet nonnullorum Pfalmorum Latinam interpretationem noftram vulgatam, \& annotatiunculas illum Iacobi de Valentia fylum redolentes, perbrewes illas ef raras. Cùm puerilem omninò rem effe deprebendiffem, tamen ad nonagefomü fextü P falmü me contuli, ibinon mo dò non reperiillud testimonium, à ligno, verüm totum illum dimidium per fum defideraui, videlicet, Dicito in gentibus quia Dominus regnauit: $\left(^{t}\right.$ tamen in toto libro quanquă plura verba \& integre fententia defiderentar',

2. ribil

Fig. 1. Versión A de la Benedicti Ariae Montani De Psalterii Anglicani exemplari animaduersio, en Biblia Sacra Hebraice, Chaldaice, Graece et Latini Philippi II Regis Catholici pietate et studio ad Sacrosanctae Ecclesiae usum (Antuerpiae, 1569-1573), tomo VIII, tratado XIV, recto del folio, Universidad de Granada, Biblioteca del Hospital Real, signatura BHR/A-006-020 (12). 
nibil tamen deeft quod fcriptum antea fuerit ; confat enim integra $\sigma^{\circ}$ continuata friptura, eaquue, vt diximus, perie recens, puncti e vocalis ex minio accentus ex Heliotropio depieti, capitales litere alizuot in initiis $P$ Jalinorum auree, fed qua Latinam magis quàm Hebraicam referant formam: ludere ne an illudere fcriba ille voluerit, jatis dignofcere non poteram. quod ad antiquitatem attinet, fiunt pictcres quantam atatem Heliotropij color ferre Dalcat; rarißime enim centefimum attingit annum. Vt antem antiquorum o diligenter friptorum exemplartum fidem fanitam, ita buiufmodi nullam efje oportuit, etiam fi mille effent reperta E lect a, nedum ronius nunquam rifi abeo, qui fummam nuctoritatem affirmare contendebat. Quod Sancto Augustino adfcribatur, foc res babet: In prioribus membranis vacuis funt vocule quedä fcripte, eo modo que fcribere jolemus, cum calamü temperantes experimur, fed à criptore pingendi litercis ridifsimo, inter alia verbailla ter aut quater funt: Hic liber, Hic liber eft, hic liber eft Sancti Augultini : atque ille quifquisfuit fcriptor, vel alius, cultello abrafit ncti Auguftini

;ita tamen vtobiecta luci membrana lectwonem integram prodat, namque atramentum tenacius haferat, quàm ivt abradere ille voluerit velpotuerit. Hinc fcilicet aftzmatio ov auctoritas libro facta eft ab iis qui Hebratè omnino ignorauerint: clarè enim legitur: Hic liber eft fa: reliqua ad lucem in rafa membrana legütur. Hac eft antiquitats or maieftas. Eft deinde alius verficulis buic fubiundius, qui $\dot{\sigma}$ fcriptoris testimonium or eius fcripturam commendat, Hic liber eft fa, fed litera nefcio qua. Porrò idem liber, vt ille babet, multis bịc Antuerpia doct is, é. Hebraicarum literarum peritis oftenfus eft. (interim dum apud nos per octo menfes integros manfit) Cbristoplioro Plantino, qui illum ad nos deferricurauit, Francifio Raphelingio Plantinigenero, Guidoni Fabritio eiusque fratri, Ioanni Harlemio, Ioanni Goropio Becano, Aluaro Nonio, doctoribus \&er alis compluribus, redditus eft à nobis. Clementiad quem pert inebat: ws que allum in fua biblotbeca Mecblinię babet: certior à nobis factus, quid thejauri in eo contineatur. Vt verò totius ret bretue pecimen preberemus, quod fatis effet ad catera cognofcenda, eum ipfum nonagefimü fextum PJalmum frdelissimè ad illam fidem defcriptü, busc noftre animaduer fioni adprimendum curauimus.

\section{PS A LM VS X C VI.}

Ex Clementis Angli exemplari defcriptus.

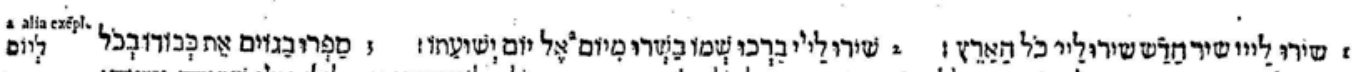

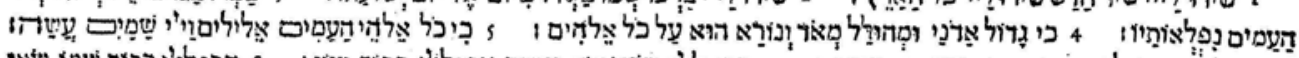

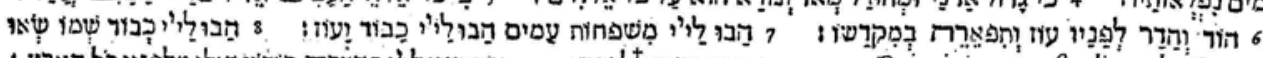

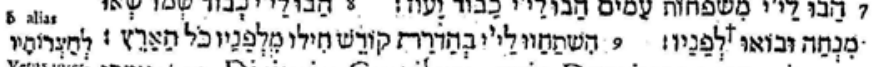

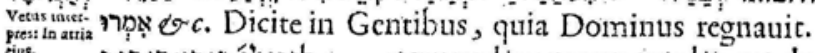

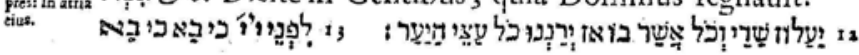

Principium verficuli io. deest, nempe

:

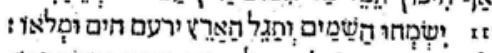

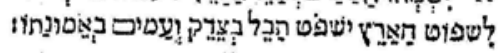

Fig. 2. Versión A de la Benedicti Ariae Montani De Psalterii Anglicani exemplari animaduersio, en Biblia Sacra Hebraice, Chaldaice, Graece et Latini Philippi II Regis Catholici pietate et studio ad Sacrosanctae Ecclesiae usum (Antuerpiae, 1569-1573), tomo VIII, tratado XIV, vuelto del folio, Universidad de Granada, Biblioteca del Hospital Real, signatura BHR/A-006-020 (12). 
Después que torné de Roma por el fin del año de setenta y dos, me digeron Plantino y Sonnio que Lindano había movido grandes tragedias y amenazas contra mí y mi nombre, y contra todos mis escriptos; y esto había sido en Lovaina y en Anveres; y como conocían su cólera, que cierto fue colérico, tanto que Juan Latomo le dijo en la cara «se numquam uidisse hominem biliosiorem»; en medio de Anveres juntó a Santiago; y en tanta maledicencia de mí le dijo el obispo Sonnio «Domine Reuerendissime, non ferimus istas detractiones et maledicentias. De absentibus bene semper dicere et tuum et meum decet oficium». Estas son palabras formales que en presencia de Plantino dijo Sonnio, a que él replicó que pues era prelado donde yo residía, me mandase le satisfaciese a la afrenta que le había hecho. Plantino respondió «¿qué afrenta os hizo? Pues no os nombra y solo advierte de la verdad manifiesta e yo os lo mostraré que aquí está el libro que yo le tengo, y nuestro reverendísimo lo ha visto y Beccano y cuantos han querido». Y a esto replicó: «ista est quam ego magnam mihi illatam queror iniuriam et appello uindicem Reuerendissimum Episcopum». A que el obispo Sonnio le preguntó: «¿Hay otra cosa de que os agraviéis sino de que escribió que no le habíades visto?»-«Istum ipsum, istum ipsum: nam profecto ipse his oculis uidi librum et habui in manu» y otras cosas a este propósito. Y así se encargó Sonnio de ordenar que yo le satisfaciese en aquella querella. Qué es lo que en esto ellos sentían, yo no lo refiero ${ }^{32}$.

El relato de Montano presenta a Lindano como una persona sin control y presa de su cólera, actitud que le acarrea la reprimenda de Plantino y del obispo de Amberes Francisco Sonnio. Pero algo de razón llevaría Lindano en su reclamación cuando, finalmente, Sonnio se encargó de ordenar que Arias Montano se retractase para tratar de solucionar el conflicto de forma pacífica. En su testimonio de los hechos, Arias Montano transmite uno solo (y el de menos importancia) de los motivos de la indignación de Lindano, el haber insinuado que no había visto con sus ojos el manuscrito que ensalzaba en su libro; pero con la coletilla «y otras cosas a este propósito» Montano oculta de forma consciente la que era principal reivindicación del obispo: que se dejase claro que él no había afirmado -como denunció Montano en su Animaduersio- que el sintagma «a ligno» se encontraba en el manuscrito hebreo del salterio.

\footnotetext{
${ }^{32}$ González CARVAJal, «Elogio histórico», 190-191.
} 
Cedamos ahora la palabra a Lindano para conocer su versión de estos mismos acontecimientos. El 3 de diciembre de 1572 el obispo escribe una carta al célebre humanista y experto en Siríaco Andreas Masio ${ }^{33}$. En este documento ${ }^{34}$ Lindano expone que Arias Montano, ya sea por temeridad o por atrevimiento intolerable, había puesto en ridículo ante el mundo entero su nombre científico, y que por ello estaba decidido a incoar contra él en la sede episcopal de Amberes una acción por difamación al amparo del canon De clerico maledico ${ }^{35}$. Posiblemente esta misma amenaza, de la que Montano no se hace eco en su versión de los hechos, fue el tema central de la conversación que Lindano mantuvo con Plantino y el obispo de Amberes en ausencia de Montano hacia el otoño de 1572. El obispo de Roermond denuncia ante Masio que Montano incurrió en su escrito en dos claras falsedades: la primera, haber dicho que él no había visto el salterio hebreo en cuestión, cuando Masio era testigo de que lo consultaron miles de veces veinte años atrás, junto con otros seiscientos estudiantes, en las clases del profesor común lovaniense Andrés Baleno; la segunda, haber afirmado que Lindano había escrito que el sintagma a «ligno» se encontraba en el manuscrito del salterio hebreo (que, como bien sabía Lindano, no conservaba tales pa-

\footnotetext{
${ }^{33}$ Cabe citar sobre este autor el reciente estudio de T. W. DunKELGRÜN, «The Hebrew Library of a Renaissance Humanist. Andreas Masius and the Bibliography to his Iosuae Imperatoris Historia (1574) with a Latin Edition and an Annotated English Translation», Studia Rosenthaliana 42-43 (2010-11), 197-252.

${ }^{34}$ Publicada en M. Lossen (hrs.), Briefe von Andreas Masius und seine Freunden: 1538 bis 1573 (Leipzig, 1886), 501-504.

${ }^{35}$ «Sic inscribitur hic titulus in quibusdam libris et in antiquis codicibus, rectius quam in uulgatis, de maledictis, quia nunc ex professo agitur de clericis etsi quaedam obiter adsperguntur de laicis. c. 2 Tertium igitur delictum clericorum est maledictum, id est, cum quis asserit alteri malum inesse, quod non inest; uel negat inesse bonum, quod inest»; cf. Giulio PACE, Isagogicorum in constitutiones imperiales libri IV, in Digesta seu Pandectas libri L, in Codicem libri XII, in Decretale libri (Lugduni, 1606), In Decretales, lib. V, 26, pág. 947. Puede leerse un amplio artículo sobre este canon en la obra de A. FACHINEI, Consiliorum liber secundus in quo quaestiones intricatissimae, ciuiles et criminales hodierno tam Germanorum quam Italorum, Hispanorum ac Gallorum foro ac quotidianae praxi accomodatissimae exacte discutiuntur et remotis obicibus nodis ac funiculis contrariis deciduntur concernens causas Electorum, Archiducum, Ducum, Principum, Comitum, Vniuersitatum, Collegiorum, Municipiorum, Nobilium ac priuatarum familiarum Germaniae ac Italiae secretiores a plurimis multis desideratis (Francofurti, 1610), 114-118.
} 
labras), lo que, según el obispo neerlandés, implicaba una acusación de falsario que le convertiría en el hazmerreír de la comunidad de estudiosos. Al mismo tiempo solicita a Masio que emita su parecer sobre la antigüedad del manuscrito hebreo del Salterio: para Montano y su equipo no tenía más de cien años; en su opinión, formada en las clases de Baleno veinte años atrás, pertenecía a los más antiguos ejemplares hebreos conservados ${ }^{36}$.

Lindano se muestra en su carta gravemente ofendido porque la falsa acusación de Montano ponía en tela de juicio su proceder científico y la calidad de todos sus escritos («Permagni namque famae nostrae interest, ne tamquam falsarii toto orbe diutius traducamur et laboribus nostris non inutiliter propugnandae catholicae nostrae religioni in lucem editis illam infamiae notam inuri patiamur»). Y por ello solicita la ayuda de un viejo amigo por la afrenta que le ha ocasionado un amigo nuevo, en alusión a Montano. Disculpándose por implicarle en este conflicto, Lindano asegura, con desesperación, que no le queda otra opción que acudir a él, porque para eso están los amigos y porque así lo exige la integridad de su nombre gravísimamente violado («uti et amici suadent et nominis mei grauissime uiolati postulat integritas»). Para concluir, Lindano comunica a Masio que se había quejado también ante algunos eruditos de la corte, quienes habían quedado estupefactos ante la calumnia de Montano («Quantopere obstupuerint ac pro me exarserint quidam in aula, ubi meam exposuisse querelam, non facile credas [...]»).

La respuesta de Masio no fue todo lo positiva que Lindano esperaba $^{37}$. Masio recibió la carta el 18 de enero de 1573 y respondió el 13 de febrero. En realidad para el ilustre orientalista no era fácil posicionarse al lado de Lindano por mucho que su antiguo compañero de clases llevara razón en su queja. La gratitud debida a Montano era muy grande: Masio fue uno de los colaboradores destacados de la Biblia Regia, con dos visibles aportaciones en el Apparatus Sacer:

\footnotetext{
${ }^{36}$ Cf. Lossen, Briefe von Andreas Masius, 503.

${ }^{37}$ Editada por H. de Vocht, «Andreas Masius (1514-1573)», en Miscellanea Giovani Mercati, vol. IV: Letteratura classica e umanistica (Città del Vaticano, 1946), 1-17.
} 
el Syrorum Peculium ${ }^{38}$ y la Grammatica Siriaca ${ }^{39}$; por ello Montano había inmortalizado su nombre citándolo y elogiándolo en el segundo prefacio general de la Biblia Regia ${ }^{40}$; por recomendación del propio supervisor de la Biblia, Masio recibió como gratificación de Felipe II una cadena con un valor de 300 escudos $^{41}$; y, por último, cuando en Roma había levantado sospechas la colaboración de Masio en la Políglota, Arias Montano se encargó de limpiar su nombre convenciendo a la curia de la erudición, ortodoxia y brillantez del orientalista belga ${ }^{42}$.

${ }^{38}$ Syrorum peculium. Hoc est, uocabula apud scriptores passim usurpata: Targumistis uero aut prorsus incognita: aut in ipsorum uocabulariis adhuc non satis explicata. Andreas Masius sibi, suae memoriae iunandae caussa coligebat. Antuerpiae. Ex oficina Christophori Plantini, Regii Prototypographi, M.D.LXXI. Este diccionario siríaco ocupa el segundo lugar entre los contenidos del volumen sexto de la Biblia Regia; este texto también tiene una segunda versión, impresa con fecha de 1572.

${ }^{39}$ Grammatica linguae syricae, inuentore atque auctore Andrea Masio: opus noum et a nostris hominibus adhuc non tractatum: quod laboriosa animaduersione atque notatione uocalium aliorumque punctorum Syricorum, quibusq. Dictionibus in optimis emendatissimisque libris appositorum ille nuper composuit. Psal. LXXI. Psal. XCIV. Antuerpiae, ex officina Christophori Plantini, Regii prototypographi, M. D. LXXI. De esta gramática, que se encuentra a continuación del diccionario siríaco en el volumen sexto de la Biblia Regia, existe una segunda versión con fecha de 1573.

${ }^{40}$ En la Eiusdem Benedicti Ariae Montani alia ad lectores praefatio in qua de totius operis usu, dignitate et apparatu ex ordine disseritur, Biblia Regia, tomo I, págs. 35-40. Cf. Sánchez Manzano, Prefacios, 58-61.

${ }^{41}$ Fue el propio Arias Montano quien inicia, en la primera mitad de 1571, una campaña en la corte de Bruselas y en la española para pagar a Masio los servicios prestados en la edición de la Biblia Regia. Su insistencia ante el duque de Alba y el rey de España obtiene sus frutos, pues el 20 de agosto de 1571 ya puede Arias Montano comunicar a Masio que fue obsequiado con una cadena de oro de seiscientos florines, que él mismo se desplazó a Bruselas para exigir de inmediato el cobro de aquel regalo, y le promete el envío de una carta del duque y de él mismo, como legado regio, explicándole las circunstancias del honorífico regalo real. En esta misma carta, Arias Montano pide a Masio que silencie su decisiva intercesión en este asunto. Cf. Arias Montano a Andrés Masio, 20 de agosto de 1571, en Macías, La Biblia Poliglota de Amberes, 258-261. El 17 de septiembre Cristóbal Plantino comunica también a Masio la noticia del regalo regio en M. Rooses-J. DenUCÉ, Correspondance de Christophe Plantin, 9 vols. (Amberes, 1883-1918 [reimpr. Nendeln, Liechtenstein, 1968]), III, 82-84 (n³ 371).

${ }^{42}$ Cf. carta de Arias Montano a Felipe II del 18 de diciembre de 1572, original en Archivo General de Simancas Estado, 583/32; transcrita en «Correspondencia del Dr. Benito Arias Montano con Felipe II, el secretario Zayas y otros sugetos desde 1568 
Por todos estos motivos, en su carta de respuesta Masio trata de impedir a toda costa que Lindano inicie el proceso de clerico maledico contra Montano. Es posible incluso que se hubiera producido algún contacto previo con el propio Montano o alguien del círculo plantiniano que solicitara a Masio mediar ante Lindano. Nada tendría esto de extraño, pues Arias Montano contó en esta polémica con la asistencia de otros muchos mediadores como los citados Plantino y Sonnio, Juan Latomo, visitador general de los canónigos reglares de Alemania y Flandes, y hasta el mismo cardenal Granvela ${ }^{43}$. En su carta del 13 de febrero de 1573, Masio reconoce no haber consultado el texto motivo de la controversia, aunque ya tenía en su poder un ejemplar de la Políglota. Comienza su escrito disculpando a Montano, a quien conocía muy bien: una persona de tanta erudición y tan alejada de toda malicia no puede haber cometido tal calumnia de forma intencionada. Sugiere Masio que quizá a Montano le haya fallado la memoria al afirmar que Lindano había dicho en su tratado lo que el obispo negaba haber escrito sobre el versículo «Regnauit a ligno». En su breve pero efectiva argumentación Masio plantea también el supuesto de que la calumnia de Montano llevara toda la mala intención posible: a Lindano le bastaría remitir a todos a la lectura de su libro De optimo scripturas inteprentadi genere, donde quedaría en evidencia, sin necesidad de juicio, la calumnia de Arias Montano. En el caso de que se llegara a incoar el proceso, Masio cree que difícilmente podría resultar favorable para Lindano habida cuenta de la fama de integridad de Arias Montano. Y si, finalmente, Lindano ganase el pleito, la acción judicial tendría gran repercusión pública y efectos negativos para ambos implicados: Montano, tras ser condenado, siempre podría plantear la excusa de que su memoria le había traicionado, pero Lindano habría incurrido ante los ojos de todos en un crimen de obstinación o pertinacia al llevar a juicio a un hombre tan ilustre por una razón tan leve.

hasta 1580», en Marqueses de Pidal y de Miraflores, Miguel Salvá, eds., Colección de documentos inéditos para la historia de España (Madrid, 1862), tomo XLI, 273-280: 276.

${ }^{43}$ Todos estos personajes aparecen citados en la carta de Arias Montano al monje cartujo Esteban de Salazar, escrita el 4 de febrero de 1594 y publicada por GonZÁLEZ CARVAJaL, «Elogio histórico», 188-193. 
Pero retomemos al curso de los acontecimientos. Siguiendo órdenes del obispo Sonnio, Arias Montano se vio obligado a escribir una larga carta de disculpa a Lindano con fecha del 13 febrero de 1573, precisamente el mismo día en que Masio remitió su carta de respuesta a Lindano. Se puede reconstruir el contenido de este documento no conservado por referencias indirectas en la correspondencia de Arias Montano ${ }^{44}$. En resumen, el biblista español se compromete a retractarse por haber afirmado que Lindano no había visto con sus ojos el manuscrito del salterio procedente de Inglaterra:

Yo en obediencia y consecuencia de todo esto, escribí una carta larga que refería lo dicho y me escusaba jurando que la verdad me había movido a testificarlo: que el libro tenía de sobras y faltas en general; y no por ofenderlo a él, que lo tenía por muy señor y amigo, y lo reverenciaba por prelado y lo estimaba por muy letrado, y que si él tenía por agravio el haber yo dicho que no había visto el libro, yo me daría por engañado por tal juicio, y lo repondría diciendo que de su afirmación sabía haberlo visto, y que de otra cosa no me advertían el obispo, Plantino y Arlemio. Que estaba yo presto a toda satisfacción en esta parte; empero que yo no consentiría en autorizar el libro, y por eso lo tenía conmigo depositado en poder de Plantino para testimonio perpetuo ${ }^{45}$.

El 10 de abril de 1573 Lindano responde a esta última carta de Arias Montano. Y lo primero que hace es lamentar que Montano hubiera dedicado la mayor parte de su extensa carta a cuestiones secundarias, y ni una sola palabra al meollo de la cuestión. En efecto, el biblista español dedicó el principio de su carta a reprochar a Lindano que hubiera ido profiriendo injurias, infamias y amenazas contra un ausente; a continuación pasó a demostrar de nuevo el escaso valor del códice inglés del salterio. En su respuesta el obispo de Roermond alterna declaraciones tópicas de amistad a Arias Montano con nuevas

\footnotetext{
${ }^{44}$ Por un lado se conserva la carta de respuesta de Lindano a Arias Montano escrita el 10 de abril de 1573 (MAcías, La Biblia Políglota de Amberes, 304-305); por otro, este último resume las principales ideas en su ya citada carta a Esteban de Salazar del 4 de febrero de 1594 (GonZÁLEZ CARVAJAL, «Elogio histórico», 188-193).

${ }^{45}$ Carta de Arias Montano a Esteban de Salazar del 4 de febrero de 1594 (GonZÁLEZ CARVAJAL, «Elogio histórico», 191).
} 
referencias al proceso eclesiástico que está dispuesto a emprender. En cuanto al salterio inglés, de cuyo valor y antigüedad no tiene dudas, lo único que hace es suscribir el parecer de su maestro Andrés Baleno y el de otros eruditos que lo manejaron en las clases de la Universidad de Lovaina. Pero Lindano dedica el resto de su carta, la parte de mayor extensión, a exponer con claridad meridiana el que considera motivo principal de su queja: el hecho de que, según la advertencia de Montano publicada en la Políglota, Lindano afirmaba que el versículo «Regnauit a ligno», eliminado en otro tiempo de los códices griegos por los judíos, se conservaba en el códice hebreo de origen inglés, lo cual era falso. Lindano explica que desde hacía veinte años sabía muy bien que aquellas palabras también habían sido suprimidas del salmo 95 (96) de aquel manuscrito del salterio, que era antiguo pero ya corrupto. El prelado neerlandés califica esta falsa denuncia de Montano como «la más indigna de todas las violaciones perpetradas contra la verdad», a la que se añade la burla de haber copiado al final de la Animaduersio el salmo 95 (96) tal y como se podía leer en el manuscrito hebreo del salterio. El perjuicio para su nombre y todos sus escritos era evidente; si Lindano no conseguía una retractación pública, quedaría como el falsario desenmascarado por el gran biblista Arias Montano. Por todo ello el obispo de Roermond exige a Arias Montano que se retracte no solo de lo que le había prometido en su carta del 13 de febrero de 1573, a saber, de la afirmación de que Lindano no había visto con sus propios ojos el manuscrito que alababa, sino, por encima de todo, de la falsa acusación de que Lindano había afirmado que el sintagma «a ligno» se conservaba en dicho manuscrito. Lindano incluso ofrece a Montano la posibilidad de excusarse por un fallo de su memoria, idea que le dio Masio en su carta de 13 de febrero.

De esta última exigencia de Lindano, que como vemos es la más importante, Arias Montano no da cuenta en su relato de los acontecimientos. Más bien creemos que de nuevo la oculta conscientemente, según se deduce del siguiente pasaje:

Luego que él recibió esta mía en Ruremunda, pasó por allí Juan Latomo, general visitador y provincial perpetuo de los canónigos reglares de Alemania y Flandes y reformador de ellos, 
que es el que tradujo a Joan Fero, y él le mostró mi carta con estas palabras: «iam conuenit mihi cum Aria Montano, nam pollicetur per epistolam se correcturum id quod scripserat, librum mihi non fuisse inspectum». Latomo le pidió la epístola y después de leída le preguntó si había más que aquello en que él se tuviese por ofendido, y él respondió que no más, y que aquello tenía por calumnia, decir yo que no había visto lo que había visto ${ }^{46}$.

La carta de Lindano del 10 de abril es una prueba irrefutable de que el obispo no se conformaba en absoluto con la media retractación que Montano expone aquí: es más, el principal motivo de la controversia era precisamente el otro, al que Lindano había dedicado la mayor parte de su carta. Todo ello nos advierte de que las negociaciones reales entre los dos teólogos en busca de una retractación pactada distan mucho de ser las que transmitió Montano en su carta de 1594. De hecho el biblista español y su círculo intentaron hasta el último momento apaciguar a Lindano para que no incoase el proceso eclesiástico y, al mismo tiempo, para que renunciase incluso a la exigencia de una satisfacción o retractación impresa. El propio Juan Latomo trató de convencer de ello a Lindano:

Juróme Latomo que con gran instancia le rogó que no tratase de tal cosa, que mejor estaba sin tal declaración mía o retractación que con ella, pues yo decía que en abonar el libro yo no mudaría cosa, porque era contra la verdad, y en el resto yo me daría por engañado, pues con tanta cólera y porfía lo había pedido al obispo Sonnio que yo obedecía por prelado. E dijo que por tres veces en diversos tiempos en un mismo día y su noche le rogó que conociese mi ánimo y no tratase de tal satisfacción, que era cargarse él más de ella; y al fin dijo que él ternía a él por contrario si no le ayudaba a persuadirme que pusiese la declaración que él pedía e yo le había ofrecido por mi carta, y así me lo dijo Latomo ${ }^{47}$.

De todo lo anterior se deduce que a Montano le costaba admitir haberse equivocado, por las prisas o por un fallo de memoria, al haber

\footnotetext{
${ }^{46}$ Carta de Arias Montano a Esteban de Salazar del 4 de febrero de 1594 (GonZÁLEZ CARVAJAL, «Elogio histórico», 191).

${ }^{47}$ Carta de Arias Montano a Esteban de Salazar del 4 de febrero de 1594 (GonZÁLEZ CARVAJAL, «Elogio histórico», 191).
} 
afirmado que Lindano decía en su tratado lo que realmente no dijo. Pero las influencias y maniobras de Arias Montano no sirvieron para disuadir a Lindano, bien curtido en controversias y, en este caso, con la fuerza de la razón. Por su parte, el obispo de Amberes Francisco Sonnio quería evitar a toda costa el proceso eclesiástico. Así que, finalmente, Montano se vio obligado por su entorno a cumplir con las exigencias de Lindano, fijar las condiciones de la retractación tras diversos contactos entre las dos partes, y reelaborar su Animaduersio para mandarla a la prensa durante el proceso de impresión de los juegos del Aparato que se estaban tirando a lo largo del año de 1573.

Todos los antecedentes expuestos hasta aquí explican la existencia de una versión B de este escrito montaniano tan distinta a la versión A, permiten comprender las causas de los cambios introducidos y aclaran por qué Lindano tampoco quedó satisfecho con el nuevo texto impreso de Arias Montano.

\section{VERSIÓN B: UNA RETRACTACIÓN NO SATISFACTORIA}

\section{1. Edición y traducción}

Transcribo a continuación el texto de la versión $\mathrm{B}$, destacando en negrita las variantes con respecto a la versión A. He consultado el ejemplar que se conserva en la Biblioteca del Arzobispado de Sevilla con signatura 5-167 (e1 en el aparato crítico). De la versión B, estudiada y traducida al castellano por E. Fernández Tejero ${ }^{48}$, no existe edición crítica moderna.

\footnotetext{
${ }^{48}$ Fernández Tejero, «Benedicti Ariae Montani... De Psalterii Anglicani exemplari animaduersio», 161-167; EADEM, «Dos tratados de Benito Arias Montano», 169-175.
} 


\section{BENEDICTI ARIAE MONTANI DE PSALTERII ANGLICANI EXEMPLARI ANIMADVERSIO}

Cum in disciplinarum ac scientiae rationibus componendis nihil magis incommodum sit, quam ut incerta pro certis habeantur, lectorem admonendum duximus non omnia, quae aliquando commendantur,

5 manuscripta exemplaria eam mereri fidem, quam ex commendantium auctoritate aestimari oportuerat. Id cum frequenti iam exemplo in aliis libris deprehenderimus in uno Anglicano Psalterio Hebraicis characteribus manuscripto manifeste indicare possumus, quod

10 exemplaris correctissimi et antiquissimi nomine a doctissimo in nostra aetate scriptore ac praecipuae in Ecclesia dignitatis uiro nobisque non uulgariter amico in libro a se composito De optimo genere interpretandi scripturas impense laudatur: eo enim in libro cum

15 auctor contendat multa in Bibliis Hebraicis loca esse deprauata et corrupta, Iudaeorum (uti dici solet) malitia, id quam diligentissime uidetur astruere ex fide uetustissimi exemplaris Psalterii, quod magno in pretio haberi in Anglia dicit idque Sancti Augustini

20 Archiepiscopi quondam Cantuariensis fuisse ait, in eoque multa esse correcta, quae in aliis Bibliis corrupta sunt, ut quod Ierusalem perpetuo scribatur et non Ierusalaim, ut in omnibus legitur aliis atque ut uere uocabatur ciuitas illa Ierusalaim, sicut a nobis

25 in Geographia est demonstratum. (Sed de hoc nomine Iesusalem, alio in loco affirmat auctor idem magis quam in illo libro).

Deinde uero unum affert locum ibidem, ut ait, integre conseruatum, in caeteris uero mutilum ex

30 Psalmo decimotertio, in quo quosdam uersus esse ait, qui in aliis non sunt קבר פתוח גרונם לטונם יחליקון. 


\section{ADVERTENCIA DE BENITO ARIAS MONTANO \\ SOBRE EL MANUSCRITO DEL SALTERIO INGLÉS}

Dado que no hay nada más perjudicial al componer los razonamientos de las disciplinas y de la ciencia que el tener lo incierto por cierto, hemos considerado poner al lector sobre aviso de que no todos los ejemplares manuscritos que algunas veces se recomiendan merecen esa confianza que habría convenido prestales en virtud de la autoridad de quienes los recomienda. Esto, puesto que lo hemos descubierto ya con frecuentes ejemplos en otros libros, lo podemos indicar de forma manifiesta en un manuscrito inglés del salterio en caracteres hebreos que es alabado hasta la saciedad por un doctísimo escritor de nuestra época, hombre de particular dignidad en la Iglesia y amigo nuestro poco común, en el libro compuesto Sobre la mejor manera de interpretar las Escrituras: en efecto, dado que el autor sostiene en ese libro que muchos lugares en la Biblia Hebrea han sido adulterados y corrompidos por la mala intención (según suele decirse) de los judíos, parece que prueba esto de la manera más diligente basándose en su fe en un antiquísimo manuscrito del salterio que dice que es considerado de gran valor en Inglaterra y afirma que el mismo manuscrito perteneció en otro tiempo a san Agustín, obispo de Canterbury: y que en él están correctas muchas cosas que están corrompidas en otras Biblias, como que siempre se escribe «Ierusalem» y no «Ierusalaim», como se lee en todos los otros; y como de verdad se llamaba aquella ciudad Ierusalaim, según hemos demostrado en la Geografía. (Pero de este nombre «Ierusalem», en otro lugar habla el mismo autor más que en aquel libro).

A continuación cita un pasaje muy importante conservado de forma íntegra, según dice allí mismo, pero mutilado en los demás, del salmo décimo tercero, en el que dice que hay ciertos versos que no están en otros manuscritos קבר פתוח גרונם לטונם יחליקון, pues así

\footnotetext{
${ }^{49}$ Salmo 13 (14), 3: «Sepulchrum patens est guttur eorum; linguis suis dolose agebant» ('su garganta es un sepulcro abierto; con sus lenguas profieren engaños'). Según Lindano, entre los versículos tercero y cuarto del salmo 13 (14) faltaba en muchas impresiones del salterio hebreo en su tiempo el versículo citado arriba, que se conservaba en el manuscrito del salterio inglés, junto con el texto siguiente: «Venenum aspidum sub labiis eorum,
} 
Sic enim ipse locum refert, cum caeteris usque ad qui quidem uersus praeterquam quod nouitatem linguae et styli a Psalterii phrasi

35 alienam his qui illius linguae gustum aliquem habent, manifeste prodant; praeter inauditum in sacris libris ac superstitiosum diuino iudicio uerbum מזל רע plane rabbinicum in illos uersiculos nescio quo consilio inductum, praeter ineptam uersiculorum illorum, et a

40 caeteris psalmi carminibus dissonantem structuram, praeter haec, inquam, omnia, non magis mihi probare uidentur exemplaris ipsius antiquitatem et auctoritatem, quam innumera alia loca in eodem libro deprauata ab ipso primo psalmo ad ultimum

45 usque, e quorum numero unus ille est, quem in Psalmi nonagesimi sexti decimo uersu, «Dicite in gentibus, quia Dominus regnauit». Auctor ille desiderari ait, uidelicet «a ligno», ut sit hemistichium: «Dicite in gentibus, quia Dominus regnauit a ligno»: partem enim

50 illam «a ligno» Iudaeorum studiosa fraude abscisam olim fuisse quidam aiunt, eiusque assertionis testem unicum Iustinum Martyrem Graecum auctorem citant. Cum uero ad huius sacri Bibliorum operis instructionem nihil non conquirendum nulli difficultati

55 uel tempori aut loco cedendum duxerimus, atque uaria Hebraica, Graeca, Chaldaica et Latina exemplaria (Deo nostros conatus promouente) comportauerimus, nacti etiam sumus illum ipsum codicem Psalterii Anglicani appellati, quem Iohannes Clemens doctissimus ac

60 pientissimus ex Thomae Mori familia possidebat. Is enim et optimi exemplaris Pentatheuci Graeci et Psalterii huius nobis copiam fecit. Sed cum Psalterium uideremus, nihil minus quam quod sperabamus reperimus. Cum primis enim neque liber antiquus est

52 martyrem e1

SEFARAD, vol. 74:1, enero-junio 2014, págs. 185-254. ISSN: 0037-0894. doi:10.3989/sefarad.014.006 
transmite él mismo ese pasaje $\mathrm{e}^{50}$, con los restantes versos hasta הלא quienes tienen algún conocimiento de aquella lengua la novedad de la lengua y del estilo extraña a la dicción del salterio, además del sintagma מזל רע inaudito en los libros sagrados y supersticioso para el juicio divino, casi rabínico ${ }^{52}$, introducido en aquellos versículos no sé con qué idea, además de la inapropiada estructura de aquellos versículos, también diferente de los demás poemas del salmo, aparte de todo esto, digo, no me parece que prueben la antigüedad y autoridad de ese mismo manuscrito más que otros muchos lugares corrompidos en ese mismo libro desde el mismo salmo primero hasta el último, uno de los cuales es aquel que se lee en el del versículo décimo del salmo nonagésimo sexto: «Dicite in gentibus quia Dominus regnauit». Aquel autor dice que se echa en falta el sintagma «a ligno» para que sea el hemistiquio «Dicite in gentibus quia Dominus regnauit a ligno»: pues aquella parte «a ligno» algunos dicen que hace tiempo fue borrada por el celoso engaño de los judíos; y como único testigo de este aserto citan a Justino Mártir. Y puesto que para la preparación del trabajo sagrado de la Biblia hemos considerado que no había que dejar nada por investigar sin ceder ante ninguna dificultad, situación o lugar y (favoreciendo Dios nuestros propósitos), hemos reunido varios manuscritos hebreos, griegos, caldeos y latinos, también no-

quorum os maledictione et amaritudine plenum est; veloces pedes eorum ad effundendum sanguinem. Contritio et infelicitas in viis eorum et uiam pacis non cognouerunt; non est timor Dei ante oculos eorum».

${ }^{50}$ Como apunta DunKelgrün (The Multiplicity of Scripture, 299), para demostrar la escasa competencia de Lindano en el manejo de la lengua santa, Arias Montano cita este versículo, el tercero del salmo 13 (14), no a partir del manuscrito hebreo del salterio, sino en la forma errónea en que aparece en el texto trascrito por Lindano en su De optimo לשונם scripturas interpretandi genere, pág. 20r donde se lee לטונם en lugar de la correcta ('lenguas').

${ }^{51}$ Salmo 13 (14), 4: «Nonne cognoscent omnes qui operantur iniquitatem» (“iAcaso no entienden todos los que hacen el mal[...]?').

${ }^{52}$ La interpolación del sintagma מזל רע (literalmente 'mal destino'), no localizable en la Biblia y de tono inapropiadamente supersticioso, es utilizado por Arias Montano como argumento para restar credibilidad a la prueba aportada por Lindano sobre el texto del salterio hebreo. El argumento, por cierto, procede de la Defensio ueritatis de Juan Isaac; cf. DUNKElGRÜN, The Multiplicity of Scripture, 300 y 317. 
65 neque ab aliquo qui | Hebraicam linguam tenuerit recte descriptus, uerum a scriba Latinas proxime praeteriti aeui literas pingendi non imperito, octoginta uel ad summum centum ab hinc annis depictus, breuis codex in membranis, charactere Hebraico quidem, uerum

70 imitatione magis ac pingendi peritia quam legendi notitia relato, adeo corrupte descriptus ut uix ullum uerbum integritatem suam retinere uideatur. Habet nonnullorum Psalmorum Latinam interpretationem non nostram uulgatam sed mixtam quandam cum

75 disiunctionibus «uel», «uel», «uel» et annotatiunculas ex uariis expositoribus breues, illum Iacobi de Valentia stylum redolentes.

Cum puerilem omnino rem esse deprehedissem, tamen ad nonagesimum sextum Psalmum me contuli; ibi

80 non modo non reperi illud testimonium «a ligno», uerum totum illum dimidium uersum desideraui, uidelicet «Dicite in gentibus quia Dominus regnauit»; et tamen in toto libro quanquam plura uerba et integrae sententiae desiderentur, nihil tamen deest quod scriptum antea

85 fuerit. Constat enim integra et continuata scriptura, eaque (uti diximus) pene recens, uocalia puncta a uigesimo quinto Psalmo et ultra ex eodem atramento, quo literae: eodemque tempore facta, ab initio uero libri ad XXV usque Psalmum, praeter atramentum, minio

90 obducta aut uiridi colore, accentus nulli, quibusdam in locis Raphe satis crebra, quae accentus speciem minus diligenter intuentibus praebent: Capitales literae aliquot in Psalmorum initiis aureae, rubrae aliae, uirides quaedam, ex heliotropio purpureae

95 multae; quae tamen omnes Latinam magis quam Hebraeam referunt formam. Quod ad antiquitatem attinet, sciunt Philosophi ac Pictores Heliotropii herbae color quantam aetatem ferre ualeat; rarissime enim centesimum integer attingit annum: sed longe 
sotros hemos dado con ese ejemplar del salterio llamado anglicano, que poseía el muy docto y piadoso señor Juan Clement, de la familia de Tomás Moro, pues este nos proporcionó un óptimo manuscrito del Pentateuco griego y este salterio. Pero al ver el salterio, no encontramos nada menos de lo que esperábamos. Para empezar el libro ni es antiguo ni ha sido transcrito por alguien que conozca la lengua hebrea, sino por un escribano que sabía dibujar las letras latinas con elegancia, de finales del siglo pasado, copiado hace ochenta o a lo sumo cien años, un manuscrito breve en pergamino, reproducido con carácter hebreo más por imitación y pericia de escribir que por conocimiento de leerlo, transcrito tan corruptamente, que apenas alguna palabra parece mantener su integridad. Tiene la interpretación de algunos salmos, no nuestra Vulgata sino una mixta con conjunciones disyuntivas «uel, uel, uel», y breves notitas de varios autores que huelen al estilo de Jacobo de Valencia. Al haberme dado cuenta de que el asunto era completamente pueril, finalmente me fui al Salmo nonagésimo sexto; allí no solo no encontré aquel testimonio «a ligno», sino que faltaba todo aquel medio versículo, es decir, «Dicite in gentibus quia Dominus regnauit». Y, no obstante, aunque en todo el libro se echan de menos muchas palabras y frases enteras, nada falta no obstante que no hubiera sido escrito antes, pues es evidente que la escritura es íntegra y continua, y esta, (como dijimos) casi reciente, los puntos vocálicos desde el salmo XXV en adelante con la misma tinta que las letras y hechos en la misma época, pero desde el inicio del libro hasta el salmo XXV, además de la tinta están cubiertos de minio o de color verde, ningún acento, en algunos lugares bastante abundantes en raphe, que dan la impresión de ser acentos si se miran a la ligera; algunas letras mayúsculas doradas en los comienzos de los Salmos, otras rojas, algunas verdes, muchas púrpuras de heliotropio; todas ellas, sin embargo, se asemejan más a la forma latina que a la hebrea.

En lo que respecta a la antigüedad, saben los filósofos y los pintores cuánta edad puede conllevar el color de la hierba del heliotropio, pues muy raramente llega a cien años; pero con mucha más claridad la escritura misma y la tinta indican que se trata de un códice casi reciente. Pero de la misma manera que es sagrada la fidelidad de los manuscritos antiguos y escrupulosamente escritos, así también convi- 
100 clarius recentem pene codicem scriptura ipsa et atramentum indicat. Vt uero antiquorum ac diligenter scriptorum exemplarium fidem sanctam, ita huiusmodi nullam esse oportuit, quamquam mille reperta essent, nedum unius adeo noui, adeoque inepti. Quod Sancto

105 Augustino liber adscribatur, sic res habet. In postremis membranis uacantibus uoculae quaedam scriptae eo modo sunt, quo scribere solemus, ubi calamum temperantes experimur, sed a scriptore literas pingendi rudissimo, inter alia uerba illa bis posita sunt «Hic

110 liber S[anc]ti Augu[stini] Cantu[riensis] liber S[anc] ti Augu[ustini] Cant[uriensis]»; atque ille quisquis fuit scriptor, uel alius, cultello abrasit ex priori loco «S[anc]ti Augu[stini] Cantu[riensis]», et in posteriori caeteris abrasis reliquit illud «liber sa.», ita tamen

115 abrasit, ut obiecta luci membrana lectionem integram prodat; namque atramentum tenacius haeserat, quam ut ille delere potuerit aut uoluerit fortasse. Hinc scilicet aestimatio et auctoritas libro facta est: clare enim legitur in posteriori loco «Liber Sa.». Reliqua

120 ad lucem in rasa membrana leguntur. Est deinde semiuersiculus ex eodem charactere subiectus qui rhythmice respondet ad illud «Liber sa. Sed litera est nescio qua». Haec codicis antiquitas maiestasque est. Porro idem liber liber ut sese habet, multis hic Antuerpiae

125 doctis et Hebraicarum literarum peritis ostensus est: redditusque a nobis Clementi ad quem pertinebat: sed eo uita defuncto, postea ad nos est rursus allatus atque in bibliotheca nostra collocatus. Vt uero totius rei breue specimen exhiberemus quod ad caetera

130 aestimanda satis esse posset, eum ipsum nonagesimum sextum Psalmum fidelissime ad illam fidem descriptum animaduersioni huic nostrae adprimendum curauimus. Videat lector quantum cum ueritate Hebraica et quantum etiam cum uulgata nostra uersione quadret. 
no que no prestásemos ninguna a un manuscrito de este tipo, por mucho que se hubiesen encontrado mil, menos aun a un solo manuscrito tan nuevo y tan inconveniente. En cuanto al hecho de que el libro se asigne a san Agustín, así está la cosa. En los últimos pergaminos en blanco hay ciertas palabritas escritas del mismo modo en que solemos escribir cuando probamos al cortar la pluma, pero por un escritor muy rudo al trazar las letras; entre otras palabras están puestas allí dos veces: «Este libro de san Agustín de Canterbury; libro de san Agustín de Canterbury». Y quien quiera que fuese el escritor u otro borró raspándolo del primer lugar «san Agustín de Canterbury», y en el segundo lugar borró las restantes palabras y dejó «libro de san»; no obstante borró de tan forma que el pergamino puesto al trasluz revela todo el texto, pues la tinta se había adherido más fuerte de lo que él pudo o quizás quiso raspar. De ahí viene, evidentemente, que hayan estimado y concedido autoridad al libro: pues claramente se lee «Libro de s.». El resto se lee a la luz en el pergamino raspado. A continuación hay un semiversículo del mismo tipo de letra colocado debajo de este que responde rítmicamente a aquello de «Este libro es de san., pero no sé con qué letra» ${ }^{53}$. Esta es la antigüedad y la majestad del códice. En su momento el mismo libro, tal y como está, aquí en Amberes fue mostrado a muchos doctos y expertos en las letras hebreas y fue devuelto por nosotros a Clemente, a quien pertenecía: pero tras su muerte, después fue traído de nuevo a nuestra casa y se encuentra depositado en nuestra biblioteca. Pero para proporcionar una breve muestra de toda la cuestión, lo que podría ser suficiente para conocer el resto, ese mismo salmo nonagésimo sexto copiado con la mayor fidelidad según el original nos encargamos de que se imprimiera junto a esta nuestra advertencia. Vea el lector cuánto se ajusta a la verdad hebrea y cuánto también a nuestra traducción vulgata $^{54}$.

${ }^{53}$ En la versión A las palabras «sed litera est nescio qua» aparecían en letra cursiva, esto es, correspondían a Arias Montano. En la versión B se imprimen en letra redonda, como un texto que forma parte del manuscrito inglés del salterio.

${ }^{54}$ Fernández Tejero («De Psalterii Anglicani exemplari animaduersio», 166-167), realiza la colación del manuscrito hebreo del salterio reproducido por Arias Montano con el texto hebreo del mismo salmo en la Biblia Políglota de Amberes, la Biblia Rabínica de Jacob ben Haim, la Políglota Complutense, los manuscritos 118-Z-42 (actualmente 


\section{2. Comentario}

En la versión B de la Animaduersio se registran muchos cambios menores de toda índole, cambios que afectan incluso al mismo título del escrito: así el sintagma preposicional «de exemplari Psalterii Anglicani» de la versión A se modifica en la nueva reimpresión del texto adelantándose el complemento del nombre, para respetar la regla gramatical de determinante antes del deteminado («de Psalterii Anglicani exemplari»). En cuanto al uso de conjunciones se observa la sustitución, en varios casos, de «et» por «ac». Otros cambios afectan al léxico («characteribus» por «litteris»), añaden precisiones (se aclara que el manuscrito perteneció a san Agustín, obispo de Canterbury, «quondam Cantuariensis fuisse ait») y liman el orden de palabras («eam mereri fidem» sustituye a «eam fidem mereri»). Asimismo se corrigen algunas erratas tipográficas de la versión A (donde decía «Clonens» se corrige «Clemens»), pero se incurre en nuevas erratas como «martyrem» por «Martyrem».

En las líneas que siguen voy a centrarme en los cambios más significativos que introduce Arias Montano en la versión B tras las complejas negociaciones con Lindano.

III. 2. 1. Arias Montano retira la insinuación de que Lindano no había visto el manuscrito

En la reimpresión de la Animaduersio Arias Montano cumple el compromiso anunciado en su carta del 13 de febrero y retira la afirmación de que Lindano no había visto el manuscrito hebreo del salterio que alababa en su tratado De optimo interpretandi scripturas genere. Así, la frase de la versión A donde formula de forma más categórica la idea de que Lindano hablaba de oídas se lee en las primeras líneas (12-15) con estas palabras: «non a se uisum sed ex alterius relatu summe laudabatur, atque

Biblioteca Histórica Marqués de Valdecilla, Ms. 1) y 118-Z-21 (actualmente Biblioteca Histórica Marqués de Valdecilla, Ms. 2) de la Universidad Complutense de Madrid (utilizados en la Políglota Complutense) y el Ms. B $19^{\mathrm{a}}$ de la Biblioteca Estatal de Rusia (San Petersburgo). El texto del salmo es idéntico en todas las citadas ediciones y manuscritos, pero en trece versos se registran no menos de quince variantes con respecto al texto del salterio inglés. 
ad grauissimae sententiae a se prolatae testimonium et argumentum citabatur in libro qui De optimo genere interpretandi scripturas inscribitur». Este aserto es sustituido en la versión B por una profesión de amistad formulada de la siguiente manera: «nobisque non uulgariter amico in libro a se composito De optimo genere interpretandi scripturas». Seguramente Arias Montano no redactó esta declaración de amistad de forma espontánea; más bien creo que Lindano pudo exigírsela. Según se desprende de su correspondencia privada, al obispo de Roermond no le agradaba la idea de pasar a la historia como el teólogo enfrentado al supervisor de la Biblia Políglota de Amberes; el tono general de la Animaduersio podría provocar esta impresión en el lector imparcial. Por ello ya en esta ocasión, como hará en otro momento posterior de su larga polémica con el biblista español, Lindano consigue de Arias Montano unas palabras que certifiquen de forma pública, aunque solo sea a modo de tópico, la amistad mutua.

Hacia la mitad de la versión A de la Animaduersio (líneas 44-47), Arias Montano lamenta que Lindano se haya dejado engañar por otros en su juicio sobre el salterio inglés, en un pasaje que tiene una clara intención exculpatoria: «Sed cum Psalterium uideremus, non potuimus non uehementer dolere grauissimo et doctissimo uiro, qui ex aliena fide scripserit et docuerit, sic turpiter esse impositum». En la versión B, Arias Montano cambia el tono de lamentación y suprime su insinuación de que Lindano había seguido el parecer de otro, dejando un lacónico «Sed cum Psalterium uideremus, nihil minus quam quod sperabamus reperimus».

Cercano ya el final de la versión A de la Animaduersio (líneas 75-77), Arias Montano insistió en la misma idea exculpatoria que articulaba su nota: «ita huiusmodi nullam esse oportuit, etiam si mille essent reperta et lecta, nedum unius nunquam uisi ab eo, qui summam auctoritatem affirmare contendebat». En la versión B se suprimen de nuevo las palabras relativas al proceder científico de Lindano y se refuerza la idea del escaso valor y el carácter reciente del manuscrito, para lo que se aporta en esta ocasión nuevas y más detalladas pruebas filológicas que en la versión A: «ita huiusmodi nullam esse oportuit, quamquam mille reperta essent, nedum unius adeo noui, adeoque inepti».

Arias Montano explica en su carta de 1594 que si afirmó en la primera impresión de la Animaduersio que Lindano no había consultado el ma- 
nuscrito hebreo personalmente fue para evitar enojar al obispo, para excusarlo del error y achacárselo a otro, para intentar evitar así una polémica que, conociendo al adversario, era muy previsible que ocurriera. Por ello Arias Montano insiste en tres ocasiones en la misma idea a lo largo de la versión A de su nota. Sea como fuere, el biblista español estaba convencido de que Lindano, por su desconocimiento de la lengua hebrea, había seguido una opinión ajena al citar y comentar el manuscrito del salterio:

Yo tuve esta por menos grave escusa, y en realidad entiendo dije verdad: porque no sabiendo él [Lindano] aun la mitad ni cuarta parte del hebreo que el Doctor León que v[uestra] p[aternidad] tanto encumbra con su buena elocuencia, y León confesaba no saber más hebreo que lo que pescaba por los vocabularios judíos y judaizantes (que este fue su lenguaje, con qué consciencia, él lo habrá ya visto), bien pude usar de esta escusa, de que el autor no había visto el libro anglicano: porque ver el libro anglicano para citarlo es entenderlo y estar cierto de lo que se dice; y con esto creí haber satisfecho a la verdad modestamente y no haber ofendido al Lindano ${ }^{55}$.

\section{2. 2. Nuevo examen del manuscrito hebreo del salterio}

Como puede apreciarse en las fotos del texto impreso de la Políglota, la versión B de la Animaduersio resulta un poco más extensa que la versión A. La mayor parte de las doce nuevas líneas de la versión B están dedicadas a profundizar en el examen pericial del manuscrito hebreo del salterio. En su carta del 13 de febrero de 1573 el biblista español confesó a Lindano estar dispuesto a retractarse de lo que pudiera haber ofendido al prelado neerlandés, pero que jamás consentiría en admitir ningún valor para el manuscrito hebreo del salterio ${ }^{56}$. En su carta de respuesta del 10 de abril de 1573, el obispo de Roermond exige ante todo, como se ha visto, que Arias Montano elimine en su reimpresión de la Animaduersio la afirmación de que Lindano había escrito que el versículo 10 del Salmo 95 (96) se podía leer en el

\footnotetext{
${ }^{55}$ Cf. carta de Arias Montano a Esteban de Salazar del 4 de febrero de 1594, en GonzÁlez CARVAJAL, «Elogio histórico», 190.

${ }^{56}$ Cf. carta de Arias Montano a Esteban de Salazar del 4 de febrero de 1594, en GonZÁLEZ CARVAJAL, «Elogio histórico», 191.
} 
manuscrito hebreo del salterio. Pero antes de esta reivindicación, que es el contenido principal de su carta y el meollo de toda la controversia, Lindano había defendido de nuevo el valor de ese manuscrito inglés, apoyándose sobre todo en la autoridad de Andrés Baleno y de otros eruditos que junto a él trabajaron sobre dicho manuscrito en Lovaina veinte años atrás. Lindano creía en la antigüedad y el valor de ese códice, que presenta como terminus ante quem non para la corrupción del original bíblico por parte de los judíos. Argumentaba para ello que en ciertos pasajes, corruptos después por los rabinos, el texto de ese códice se acercaba más a la traducción Vulgata; que la división de los Salmos coincidía con la canónica; y que algunos de sus versículos y hemistiquios faltaban en los manuscritos rabínicos del siglo XVI. Según Lindano, un examen detenido y objetivo de cada uno de los aspectos del manuscrito permitiría salvar todas las críticas que Arias Montano y su equipo habían hecho al mismo.

Dado que el biblista español no tenía otra opción que plegarse a las dos principales reclamaciones de Lindano (me refiero de nuevo a la afirmación de que el teólogo flamenco no había consultado personalmente el manuscrito y a la controvertida afirmación sobre el sintagma «a ligno»), en la versión B de su advertencia carga aun más las tintas contra el manuscrito hebreo, rectificando algunos datos incorrectos de la versión A, ampliando otros y aportando nuevas pruebas procedentes de un segundo examen de ese manuscrito. La batalla personal contra Lindano estaba prácticamente perdida, pero la cuestión no estaba tan clara en el debate de fondo sobre la antigüedad del propio manuscrito y el valor del original hebreo del Antiguo Testamento. Por ello, Arias Montano trata de poner el foco sobre ese códice y difuminar las referencias a su oponente en la nueva redacción de la Animaduersio.

Las dos versiones de la Animaduersio permiten reconstruir parte de la historia de un manuscrito que, según creía Lindano, pudo pertenecer a san Agustín, obispo de Canterbury, hacia el 608 d. C., había formado parte de la biblioteca de algún familiar de Tomás Moro y, durante los años de la edición de la Biblia Políglota, estaba en poder del médico y humanista Juan Clemente, yerno y secretario de Moro, que tenía su valiosa biblioteca instalada en Malinas, a donde se exilió huyendo de la persecución del catolicismo en su país. Theodor W. Dunkelgrün realiza una aportación decisiva en este punto: este investigador ha demostrado que el salterio 
objeto de la polémica se encuentra en la Biblioteca Universitaria de Leiden con la signatura Ms. Or. $4725^{57}$. Su minucioso cotejo del manuscrito con la descripción ofrecida por Arias Montano en la versión B de la Animaduersio no deja duda alguna de la certeza de este feliz descubrimiento. Dunkelgrün recoge también lo que la bibliografía precedente transmite sobre la historia ya conocida de ese manuscrito: formaba parte de la biblioteca de la Abadía de san Agustín de Canterbury, en cuyo catálogo de 1497 se menciona el códice (de ahí, por cierto, la errónea atribución a san Agustín de Canterbury por parte de Lindano), de donde se prestó a Humphrey, duque de Gloucester, quien lo vendió a Enrique VI, pasando a formar parte de los fondos del King's College, en Cambridge, de donde fue a parar a las manos de William Roper (1496-1578), yerno de Tomás Moro. A partir de aquí el principal estudioso de este manuscrito, G. I. Lieftinck $^{58}$, dio un salto hasta Francisco Rafelengio, cuya marca de propietario puede verse en un trozo de papel aparte del manuscrito. En 1990 Alastair Hamilton demostró que este manuscrito, que durante mucho tiempo se pensó que había formado parte de la donación de José Justo Escalígero (1550-1609) a la Biblioteca de la Universidad de Leiden, solo entró en dicha biblioteca cuando se subastaron los libros y manuscritos de Francisco Rafelengio en 1626, y en un momento posterior fue colocado en la misma caja de los libros de Escalígero conservados en Leiden ${ }^{59}$. Gracias a los datos aportados por la Animaduersio montaniana, Dunkelgrün rellena el vacío existente en la bibliografía previa sobre la historia del manuscrito que media entre William Roper y Rafelengio: Juan Clement tuvo en su poder dicho manuscrito hasta el verano de 1572, y desde entonces este volumen pasó a formar parte de los fondos de la imprenta de Plantino, hasta que Rafelengio, probablemente hacia 1586, se lo llevó a Leiden, donde se hizo cargo de una rama del negocio tipográfico de Plantino y dio clases de hebreo en la universidad a partir de $1587^{60}$.

${ }^{57}$ Cf. DunKelgrün, The Multiplicity of Scripture, 306-319.

${ }^{58}$ Cf. G. I. Lieftinck, «The Psalterium Hebraycum from St. Augustine's Canterbury Rediscovered in the Scaliger Bequest at Leiden», Transactions of the Cambridge Bibliographical Society 2 (1955), 97-104.

${ }^{59}$ Cf. A. Hamilton, «Franciscus Raphelengius: The Hebraist and his Manuscripts», De Gulden Passer 68 (1990), 105-117: 112-113.

${ }^{60}$ Cf. Dunkelgrün, The Multiplicity of Scripture, 314. 
En la versión A de la Animaduersio Arias Montano explica que, durante el proceso de adquisición de manuscritos para la confección de la Biblia, Juan Clement les proporcionó dicho códice, que tenía conservado como un tesoro («nacti etiam sumus illud exemplar Psalterii appellatum Anglicanum, quod tanquam thesaurum magnum diligentissime conseruatum Ioannes Clemens doctissimus et pientissimus uir ex Thomae Mori familia possidet, is enim et optimi exemplaris Pentatheuci Graeci et huius Psalterii nobis copiam fecit»); que tuvo este ejemplar en su poder durante ocho meses completos («interim dum apud nos per octo menses integros mansit»), referencia que permite datar este primer préstamo desde abril o mayo de 1571 hasta 13 de enero de 1572, fecha del prefacio que antecede a la Animaduersio; y que, finalmente se devolvió el salterio a su dueño haciéndole saber el juicio negativo sobre su valor al que había llegado el equipo de la Políglota de Amberes («redditus est a nobis Clementi ad quem pertinebat; isque illum in sua bibliotheca Mechliniae habet: certior a nobis factus quid thesauri in eo contineatur»). La devolución pudo tener lugar entre el 13 de enero de 1572 y finales de abril de ese mismo año, cuando Arias Montano parte hacia Roma.

Pero el destino quiso que Clement falleciera poco después, el 1 de julio de 1572. Y puesto que el manuscrito del erudito inglés fue el centro de la controversia que Lindano suscitó en el otoño de ese mismo año, el titular de la imprenta plantiniana consiguió traerse este valioso ejemplar de Malinas y tenerlo en depósito de forma permanente en Amberes. Todos estos hechos se recogen en la versión B de la Animaduersio con la sustitución del texto de la versión A «redditus est a nobis Clementi ad quem pertinebat; isque illum in sua bibliotheca Mechliniae habet: certior a nobis factus quid thesauri in eo contineatur» por este otro: «redditusque a nobis Clementi ad quem pertinebat: sed eo uita defuncto, postea ad nos est rursus allatus atque in bibliotheca nostra collocatus». Asimismo el tiempo verbal de presente de la versión $\mathrm{A}$ en la frase «quod tanquam thesaurum magnum diligentissime conseruatum Ioannes Clemens doctissimus et pientissimus uir ex Thomae Mori familia possidet» se modificó en la versión B, tras la muerte de Clement, a pretérito imperfecto («quem Iohannes Clemens doctissimus ac pientissimus ex Thomae Mori familia possidebat»).

Así pues, la posesión de forma indefinida del manuscrito de Clement permitió a los editores de la Políglota realizar un nuevo examen en pro- 
fundidad del texto antes de la obligada reimpresión de la Animaduersio y refutar con más detalles los argumentos que Lindano había expuesto a favor del manuscrito en su carta del 10 de abril de 1573. El resultado de esta revisión es que se limaron errores cometidos en la versión A y se aportaron nuevas evidencias acerca del escaso valor de dicho manuscrito. Veamos las principales novedades:

- Se insiste en que el copista del manuscrito del salterio puede ser alguien del siglo XV, y no más atrás: el texto de la versión $\mathrm{A}$ «sed a scriba Latinas eleganter pingendi literas non ignaro» se cambia en la versión B por «uerum a scriba Latinas proxime praeteriti aeui litteras pingendi non imperito».

- Se precisa que el manuscrito está escrito en pergamino: de la versión A «liber charactere Hebraico» se pasa en la versión B al texto «codex in membranis, charactere Hebraico quidem».

- En la versión A de la Animaduersio Arias Montano declara que el manuscrito en cuestión tiene la traducción vulgata de algunos salmos («Habet nonnullorum Psalmorum Latinam interpretationem nostram uulgatam»). En la versión B se rectifica y se anota que la versión latina de algunos salmos no procede de la Vulgata, sino una mixta con diferentes posibles traducciones latinas separadas por las conjunciones disyuntivas «uel», «uel», «uel» («Habet nonnullorum Psalmorum Latinam interpretationem non nostram uulgatam sed mixtam quandam cum disiunctionibus «uel», «uel», «uel»»).

- En la versión A se lee que el manuscrito contiene muy breves y escasas notitas que huelen al estilo de Jacobo de Valencia («et annotatiunculas illum Iacobi de Valentia stylum redolentes, perbreues illas et raras»); en la versión B se matiza que esas notas son simplemente breves (se suprime «raras») y que, aunque huelen al estilo de Jacobo de Valencia, proceden de varios autores («et annotatiunculas ex uariis expositoribus breues, illum Iacobi de Valentia stylum redolentes»).

- En la versión A se hace una referencia, más bien vaga y confusa, al hecho de que los puntos y acentos están pintados de 
minio (color rojo) y de heliotropio (azul violeta) («puncti et uocalis ex minio accentus ex Heliotropio depicti») y que algunas mayúsculas de los comienzos de los salmos son doradas («capitales literae aliquot in initiis Psalmorum aureae»). En la versión B se introducen nuevas precisiones que vienen a aclarar las indicaciones de la versión A: la vocalización desde el salmo XXV en adelante es de la misma tinta negra que el texto consonántico, pero en los primeros veinticinco salmos los puntos están repasados, además de con la tinta, con minio o con color verde, y no hay ningún acento, siendo algunos lugares muy abundantes en el diacrítico raphe («uocalia puncta a uigesimo quinto Psalmo et ultra ex eodem atramento, quo literae: eodemque tempore facta, ab initio uero libri ad XXV usque Psalmum, praeter atramentum, minio obducta aut uiridi colore, accentus nulli, quibusdam in locis Raphe satis crebra, quae accentus speciem minus diligenter intuentibus praebent»). En cuanto a las mayúsculas iniciales de los Salmos, en la segunda impresión de la Animaduersio se especifica que algunas son doradas, como se afirmaba en la versión A, pero que otras son rojas, algunas verdes y muchas purpúreas de heliotropio («in Psalmorum initiis aureae, rubrae aliae, uirides quaedam, ex heliotropio purpureae multae»).

- Sobre la edad del manuscrito, la versión A plantea la hipótesis de, como mucho, cien años por el uso del heliotropio, que los pintores saben que no es antiguo ( Quod ad antiquitatem attinet, sciunt pictores quantam aetatem Heliotropii color ferre ualeat, rarissime enim centesimum attingit annum»). En la versión B se considera a los filósofos también expertos en el uso como tinta de la planta del heliotropio y se apostilla que, además de esta prueba, la escritura y el resto de la tinta hacen muy plausible la hipótesis de que el salterio anglicano sea un manuscrito más bien reciente («Quod ad antiquitatem attinet, sciunt Philosophi ac Pictores Heliotropii herbae color quantam aetatem ferre ualeat; rarissime enim centesimum integer attingit annum: sed longe clarius recentem pene codicem scriptura ipsa et atramentum indicat»). 
- En cuanto al poseedor del manuscrito, la versión B también añade nuevos datos procedentes de un examen más detallado del códice. En principio se corrige las palabras que, según Arias Montano, se podían leer manuscritas en las primeras páginas del códice (en las últimas páginas del códice según la versión B): donde la versión A decía «Hic liber, hic liber est, hic liber est sancti Augustini», la versión B dice «Hic liber Sti. Augu Cantu. liber Sti. Augu Cant.». En la versión A leemos que alguien posteriormente borró «ncti Augustini» y quedó solo «liber est sa», aunque lo borrado se podía ver al trasluz; en la versión B se matiza que el texto borrado fue, en la primera parte, «Sti. Augu Cantu.», y en la segunda «ti. Augu Cant.», quedando solo «liber sa». Aquí observamos una incoherencia en la versión B, pues, según el nuevo texto de las primeras páginas del manuscrito, tras el borrado solo podría haber quedado «liber S.» y no «liber sa.»: estamos, por tanto, ante un cruce entre las versiones A y B.

- En la versión A Arias Montano denuncia la ignorancia del hebreo de quienes confirieron autoridad y antigüedad al manuscrito objeto de controversia ( $«$ Hinc scilicet aestimatio et auctoritas libro facta est ab iis qui Hebraice omnino ignorauerint»); en la versión B Arias Montano retira estas palabras para rebajar el tono de la polémica («Hinc scilicet aestimatio et auctoritas libro facta est»).

- Finalmente, la primera versión de la Animaduersio citaba los nombres de los testigos, muchos de ellos expertos en hebreo, a quienes había mostrado el manuscrito en cuestión: «Porro idem liber, ut ille habet, multis hic Antuerpiae doctis et Hebraicarum literarum peritis ostensus est (interim dum apud nos per octo menses integros mansit) Christophoro Plantino, qui illum ad nos deferri curauit, Francisco Raphelingio Plantini genero, Guidoni Fabritio eiusque fratri, Ioanni Harlemio, Ioanni Goropio Becano, Aluaro Nonio, doctoribus et aliis compluribus». En la versión B se suprimen los nombres de todos ellos, posiblemente para alejarlos y protegerlos de la polémica con Lindano y de todas las posibles consecuencias posteriores, y se sustituye por una referencia general a muchos eruditos y expertos en hebreo («Porro idem liber, ut ille habet, multis hic Antuerpiae doctis et Hebraicarum literarum peritis ostensus est»). 
III. 2. 3. «Regnauit a ligno Deo»: affirmatne Arias Montanus? Negat Lindanus

Y llegamos así al motivo central de la discordia entre Lindano y Arias Montano, formulada por el obispo de Roermond con las siguientes palabras: «[...] testatur enim illud «A ligno», ais, in hoc Psalterio (Anglicano) esse; quod an usquam illis meis De optimo genere libellis uel nunc tibi relectis agnoueris, percuperem cognoscere» ${ }^{61}$. Toda la cuestión podría quedar cerrada, según Lindano, si el biblista español se retractaba en su nueva Animaduersio de haber afirmado, como por un fallo de su memoria, que el obispo de Roermond había declarado que el versículo 10 del salmo 95 (96) se conservaba en el salterio hebreo ( Quod si et hunc memoriae tuae tot linguarum, tot disciplinarum, tot denique rerum imprimis praeclararum cognitione uaria peronustae lapsum deprecaris, sicuti et de illo altero tuo pronunciato, me nunquam illum Anglicanum uidisse codicem, sed ex aliena fide, ais, me istud scripsisse et docuisse, mihique turpiter esse impositum tandem agnoscis, perfacilis equidem ignosco») ${ }^{62}$. Recordemos que en su carta del 13 de febrero de 1573 el biblista español solo ofrecía a Lindano suprimir en su nuevo texto la insinuación de que Lindano no había visto el manuscrito con sus propios ojos. En su respuesta del 10 de abril, el prelado neerlandés deja claro que el meollo de la controversia estaba en dirimir cuál de los dos teólogos decía la verdad: si Arias Montano al afirmar que Lindano había escrito que el versículo «Dicite in gentibus, quia Dominus regnauit a ligno» se conservaba íntegramente en el salterio anglicano, o si Lindano al desmentir tal afirmación. El tono del teólogo flamenco se eleva al expresar cómo se había sentido tras la falsa denuncia de Arias Montano: «immo infamaris falsi crimine»; «Quantum uero me ex isthac tua infamatrice ac uere stileutica epistola sequatur dedecus, quanta infamia, quantum nominis mei (quo nihil mihi unquam fuit charius, nihil antiquus) detrimentum, agnoscis ipse; quod caeteris scriptis meis omnibus perpetua ista inusta haeret nota»; «An non Lindanus omnium iudicio damnetur falsi notatus? An non Lindanus pronun-

\footnotetext{
${ }^{61}$ MAcías, La Biblia Poliglota de Amberes, 300-301.

${ }^{62}$ Macías, La Biblia Políglota de Amberes, 300-301.
} 
cietur ab Aria Montano demonstratus falsarius?» ${ }^{63}$. Arias Montano no consideraba que tal afirmación pudiese ofender tanto a Lindano, a quien ni siquiera había citado por su nombre. De nada le servía esta excusa a su oponente: el daño era el mismo pues su nombre estaba asociado al título Sobre la mejor manera de interpretar las escrituras, de gran impacto en toda Europa.

Así pues, en su carta de abril de 1573 Lindano exige de forma tajante que Arias Montano publique una satisfacción pública y clara a la infamia cometida contra su nombre y su reputación escrituraria ${ }^{64}$. El problema es que el resultado de esta controversia no podía ser otro que uno de los dos implicados quedara como falsario ante el biblismo de la época: Arias Montano, si corregía la versión A de su texto y admitía que Lindano no había afirmado lo que antes había declarado; o Lindano, si el nuevo escrito insistía en la acusación de que Lindano había afirmado que el versículo del Salmo 95 (96) se leía en el salterio inglés.

Jueces imparciales ya habían examinado el escrito de Arias Montano y habían dado la razón a Lindano en lo tocante al sintagma «a ligno». El obispo de la diócesis de Amberes, autoridad ante la que Lindano pretendía incoar el proceso de clerico maledico, habría tenido que comprobar con sus ojos si Lindano había afirmado en su $D e$ optimo interpretandi scripturas genere lo que Arias Montano declaraba. En algún momento de finales de 1572 y principios de 1573 este último y su equipo debieron de comprobar que incurrieron, al leer los párrafos ya estudiados del De optimo interpretandi scripturas genere, en el error de lectura e interpretación que Lindano catalogaba como flagrante difamación. A Arias Montano no le quedaba otra opción, pues, que rectificar en este punto crucial de su controversia con Lindano para frenar el proceso eclesiástico que se le venía encima. Pero adelantamos ya aquí que su retractación no fue, en este particular, todo lo clara que Lindano hubiese deseado: el humanista español,

\footnotetext{
${ }^{63}$ MaCías, La Biblia Políglota de Amberes, 300-303.

${ }^{64}$ «Tu ergo tandem tecum statue, uir prudentissime atque, uti profiteris, a puero ueritatis amantissime, quanam ratione famam meam uiolatam mihi restituas illibatam, quonam modo inustae ignominiae notam deleas»; cf. MAcíAs, La Biblia Políglota de Amberes, 302.
} 
en efecto, se desdice de las afirmaciones erróneas de la versión A, pero la redacción final de su texto tiene la intención de disimular la misma retractación, y aun cumpliendo lo que Lindano exigía, parece que dice lo mismo que en la versión A. Veamos cómo se refleja todo esto en la versión B de la Animaduersio:

Ante todo cabe insistir en el hecho de que Arias Montano se pliega por completo a las exigencias de Lindano y rectifica el error cometido en la versión A en relación al sintagma «a ligno». En efecto, donde la versión A decía, como resultado de una lectura equivocada, que según Lindano el versículo 10 del salmo 95 (96) se conservaba en el manuscrito hebreo del salterio, en la versión B se corrige que lo que Lindano había dicho que se conservaba en el manuscrito hebreo era un versículo del salmo 13 (14):

\section{Versión A:}

[...] Deinde unum maximi momento affert locum, ibidem, ut ait integre conseruatum, in ceteris uero mutilum. Id est Psalmi nonagesimi sexti decimus uersus «Dicite in gentibus quia Dominus regnauit a ligno» $[. .$.$] .$

\section{Versión B:}

[...] Deinde uero unum affert locum ibidem, ut ait, integre conseruatum, in caeteris uero mutilum ex Psalmo decimotertio, in quo quosdam uersus

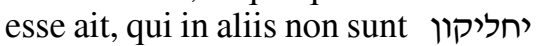
קבר פתוח גרונם לטונם. Sic enim ipse locum refert, cum caeteris usque ad [...] הלא ידעו כל פועלי און

Con esta nueva redacción Arias Montano corregía la falsa denuncia contenida en la versión A y complacía la exigencia formulada por Lindano en su carta del 10 de abril de 1573 . En este punto podría haber concluido la controversia particular entre ambos biblistas si aquel no se hubiese empecinado en conservar en la versión B de la Animaduersio las citas y las referencias al versículo 10 del salmo 95 (96) que articulaban su errada argumentación de la versión A. ¿Por qué motivos? Podríamos barajar desde cuestiones de imprenta, para modificar el texto lo menos posible, hasta la intención de disimular de alguna manera el error cometido en la versión A. El caso es que, en efecto, tras el texto copiado más arriba sobre el salmo decimotercero, Arias Montano redacta un farragoso período sintáctico en el que desglosa algunos puntos débiles del texto conservado en el manuscrito del salterio que Lindano citaba como prueba de su valor: 
[...] qui quidem uersus praeterquam quod nouitatem linguae et styli a Psalterii phrasi alienam his qui illius linguae gustum aliquem habent, manifeste prodant; praeter inauditum in sacris libris ac superstitiosum diuino iudicio uerbum מזל רע plane rabbinicum in illos uersiculos nescio quo consilio inductum, praeter ineptam uersiculorum illorum, et a caeteris psalmi carminibus dissonantem structuram, praeter haec, inquam, omnia [...].

Obsérvese la complejidad del período que comienza con un pronombre relativo «qui» cuyo antecedente atraído es «uersus», que se desarrolla a continuación en forma de cuatro incisos de mayor a menor extensión (el primero como una oración subordinada introducida por la conjunción «praeterquam», cuyo verso es «prodant», los dos siguientes con la preposición «praeter» más acusativo, y el cuarto formulado a modo de síntesis y conclusión con las palabras «praeter haec, inquam, omnia»), y que termina cinco líneas más abajo con el juicio negativo sobre el valor de los versos que analiza, juicio que Arias Montano hace extensible -y aquí es donde conecta el texto de la versión B con el de la versión A- a otros muchos lugares corrompidos desde el salmo primero hasta el último, entre los cuales un caso famoso es el polémico pasaje que se encuentra en el versículo $10 \mathrm{del}$ salmo 95 (96):

non magis mihi probare uidentur exemplaris ipsius antiquitatem et auctoritatem, quam innumera alia loca in eodem libro deprauata ab ipso primo psalmo ad ultimum usque, e quorum numero unus ille est, quem in Psalmi nonagesimi sexti decimo uersu, «Dicite in gentibus, quia Dominus regnauit».

Conforme avanza la segunda versión de la Animaduersio la retractación del biblista español se va enturbiando cada vez más. En la versión A Arias Montano afirmaba que Lindano había declarado que el versículo «Dicite in gentibus, quia Dominus regnauit a ligno» se conservaba en el manuscrito del salterio mientras que se había perdido en otros códices posteriores por la maldad de los judíos; en la versión B explica que Lindano echa en falta el sintagma «a ligno» en el versículo del salmo 95 (96) para que se complete el hemistiquio: 


\section{Versión A:}

[...] testatur enim illud, a ligno, in hoc Psalterio esse, quod Iudaeorum malitia olim euulsum inde sit ut ex Iustino Martyre auctore Graeco ipe aliique citant.

[...]

\section{Versión B:}

Auctor ille desiderari ait, uidelicet «a ligno», ut sit hemistichium: «Dicite in gentibus, quia Dominus regnauit a ligno»: partem enim illam «a ligno» Iudaeorum studiosa fraude abscisam olim fuisse quidam aiunt, eiusque assertionis testem unicum Iustinum martyrem Graecum auctorem citant.

La nueva redacción de la Animaduersio nos deja un texto que no hace honor a la verdad completamente. Arias Montano sustituye el aserto erróneo de la versión A por una media verdad en la versión B, puesto que Lindano no expone en ningún lugar de su libro De optimo scripturas interpretandi genere que eche en falta el sintagma «a ligno» por una cuestión de métrica; y cuando se refiere a este ejemplo, remite claramente al testimonio de Justino Mártir. El problema es que en una lectura rápida, un lector apresurado podría perderse fácilmente en el laberinto sintáctico creado por Arias Montano e interpretar que, según Lindano, el versículo 10 del salmo 95 (96) se podía leer también en el manuscrito hebreo del salterio, aunque no sea eso precisamente lo que dice la versión B. Esta lectura quedaría reforzada cuando, avanzando el texto, Arias Montano no modifica ni una sola palabra del siguiente pasaje:

Cum puerilem omnino rem esse deprehedissem, tamen ad nonagesimum sextum Psalmum me contuli; ibi non modo non reperi illud testimonium «a ligno», uerum totum illum dimidium uersum desideraui, uidelicet «Dicite in gentibus quia Dominus regnauit» $[\ldots]$

De la lectura de estas líneas, que también se leían en la versión A, se sigue deduciendo que Lindano había afirmado que el versículo «Dicite in gentibus, quia Dominus regnauit a ligno» se conservaba en el manuscrito hebreo del salterio.

$Y$ ya al final del texto, Arias Montano insiste en transcribir de nuevo el salmo 95 (96) tal y como se podía leer en el manuscrito inglés del salterio. En la versión A la principal intención de esta transcripción era 
que el lector comprobara con sus propios ojos que en el salterio inglés no conservaba el versículo que Lindano, presuntamente, había afirmado que estaba allí; véase la acotación que hace Arias Montano en el lugar correspondiente de la copia del salmo 95 (96) «Principium uersiculi 10 deest, nempe Dicite in Gentibus, quia Dominus regnauit»; esta prueba suponía el golpe de gracia final contra la tesis de Lindano y los detractores del texto hebreo de la Biblia:

Vt uero totius rei breue specimen praeberemus, quod satis esset ad caetera cognoscenda, eum ipsum nonagesimum sextum Psalmum fidelissime ad illam fidem descriptum, huic nostra animaduersioni adprimendum curauimus.

En la versión B, dado que Arias Montano se vio obligado a retirar su falsa acusación sobre el sintagma «a ligno», y debía justificar, de alguna forma, el mantener la transcripción del salmo 95 (96) del salterio inglés, amplía con una frase el párrafo final: su intención, ahora, al copiar este texto es que el lector pueda comprobar cuánto se diferencia ese manuscrito alabado por Lindano de las principales fuentes de la verdad hebraica y de la propia Vulgata, tan alabada por los «misohebreos».

Vt uero totius rei breue specimen exhiberemus quod ad caetera aestimanda satis esse posset, eum ipsum nonagesimum sextum Psalmum fidelissime ad illam fidem descriptum animaduersioni huic nostrae adprimendum curauimus. Videat lector quantum cum ueritate Hebraica et quantum etiam cum uulgata nostra uersione quadret.

En resumidas cuentas, en la versión B de su Animaduersio Arias Montano se reafirma en su tesis de que el manuscrito hebreo del salterio alabado por Lindano no tiene ningún valor, pero se ve obligado a retractarse de varias ideas centrales de su primer texto: suprime, en primer lugar, toda insinuación de que Lindano no había consultado personalmente el manuscrito del salterio; y rectifica, en segundo lugar, al declarar que el obispo había dicho que lo que faltaba en dicho manuscrito era el versículo tercero del Psalmo 13 (14). Lo que hemos detectado aquí es que Arias Montano parece no querer modificar en exceso la estructura del texto en su versión A y, para ello, a pesar 
de corregir el pasaje donde acusaba a Lindano de haber dicho que el versículo 10 del salmo 95 (96) se conservaba íntegro en el salterio, conserva los párrafos principales que tratan sobre el salmo 95 (96), que articulaban la argumentación de su versión A. Todo ello difumina la retractación de Arias Montano y podría inducir al lector a seguir interpretando que Lindano había dicho que dicho versículo también estaba en el salterio inglés. Si a esto le unimos que aquel no cambia la indicación «finalmente me fui al Salmo nonagésimo sexto; allí no solo no encontré aquel testimonio a ligno, sino que faltaba todo aquel medio versículo, es decir, Dicite in gentibus quia Dominus regnauit», y vuelve a transcribir el salmo 95 (96) al final para que el lector juzgue la incompetencia de Lindano, resulta que la rectificación de Arias Montano no estaba zanjada ni clara en este punto, que para el obispo de Roermond era crucial.

\section{3. Datación}

Los cambios comentados hasta aquí permiten fechar la versión B de la Animaduersio entre el 10 de abril y agosto de 1573, fecha en que concluyeron los trabajos de impresión de la Políglota de Amberes. En efecto, la retractación parcial que Arias Montano ofreció a Lindano en su carta del 13 de febrero (se comprometía a borrar todas aquellas palabras que insinuaran que Lindano hablaba de oídas al alabar el salterio hebreo, sin haberlo consultado personalmente) no satisfizo al obispo de Roermond, quien respondió en una extensa carta del 10 de abril defendiendo, por una parte, el valor del manuscrito hebreo del salterio y, por otra, exigiendo que el biblista español se retractara claramente de la cuestión del «a ligno». En la versión B de la Animadversio Arias Montano suprime por completo las insinuaciones de que Lindano no había visto el manuscrito hebreo, examina con más detenimiento el mismo manuscrito para reafirmarse en su opinión del escaso valor del mismo, y trata de complacer también a Lindano en relación a la cita del sintagma «a ligno», aunque sin demasiado éxito. Es decir, el nuevo escrito de Arias Montano fue redactado con toda seguridad después de la recepción de la carta de Lindano del 10 de abril, cuyo contenido permite comprender los principales cambios introducidos por aquel en su Animaduersio. 
cùm id in nullis aliis vel Chaldzeorum, vel Grxcorum, vel Latinorum libriscontingere videamus. Effo autem \& fuiffe antiquiflimum huius Mazzoreth vfum, atque ab ipfis Ifraclitarum primis ferè calamitatibus narum, tum res ipfa, qux ferè, ve diximus, pronuntiarionis varietate conftat, rum eriam Hebreorum doetörum libri omnes docent, quibus h.re M A Z Z O RET H auctoritas frequenter citatur. Sunt nobis integra Biblia Hebraica manufcripta ante annos, ve feriptura indicar, quadringentos: funt in Complutenfi bibliotheca noftris antiquiora:elegantifima vidimus Bononix in Prxdicatorum monafterio, \& in Canonicorú canobio ; vidimus Mediolani apud Dominicanos optima \& antiquiflima cxemplaria: in quibus omnibus conftantifsima \& fibiomnino confentiens M A z z O R E TH adferipta eft eadem qux in $\mathrm{Venetis} \&$ in Bomber gianis codicibus circumfertur. Hanc autem quòd non minus vtilem quàm caxterx in aliis linguis variat lectioncs, imò prxter cxteras vtilifstmam fore arbitraremur, huic facro Regiorum Bibliorum Apparatui addendam quàm fidelifsimè curauimus, addita interpretatione corum verborum, qux non Grammaticatantùm ratione, fed fignificatione ipfa difcreparc obferuantur: ve doet tis lector, vtraque lectione fimul compofita, in arcano illo fentétix inuenienda genere exerceatur. ipfe enim virrò v bi hane rationen inueneric, planè iudicabit neutram partem effe meritò reiiciendam.

POR Rò verba ad indicandam varietarem lectionis, iam inde à principio in Mazzoreth vfurpara

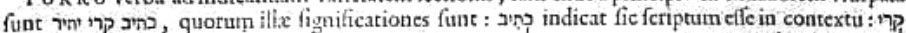
verò ita legi foletc; Hxc igitur quicunque attentè atque $x$ quo animo legerit omnia, intelliget nimirum vel temporum in iuria, vt credere par eft, vel Iudxorum inuidin,vt quidam accufare volunt(qui tamen neque auctorem, neque tempus, neque argumentum certum, quamobrem ludxi id fecerint, indicanr) non tantam calamicatem efle allatam, quantam apud huius Mazzoreth antiquifsime ignaros exclanari audimus. Quod fupereft, illud eft, Chriltianum omnem lectorem admonere \& obfecrare, ve omnibus ins lectionibus, qux ad diuini verbi explicationem \& cognitionem pertinene, vnotantùm pietatis exercend $x$ \& promouend $x$ ftudio ductus vtatur; fugiat verò contentionem, cuius nullus vnquam in pietatecolenda probatus vfus fuit. Datum Antucrpix, Idib. Ianuariis. 1572.

\section{BENEDICTI ARIE MONTANI DE PSALTERII ANGLICANI EXEMPLARI ANIMADVERSIO}

(1)

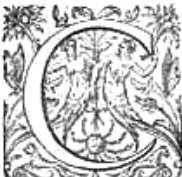

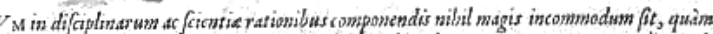

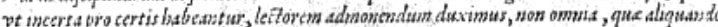

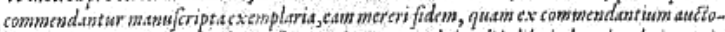

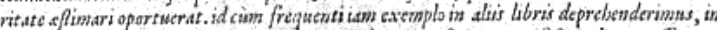
mo Anglicano Pfalterio Hebracis claraficribus manuf cripto matiffefe indicare poffamus, quod exemplaris correctif simi (c) antiquefsimi nomize, a doctiffimo in noffra etate friptore,

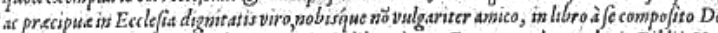

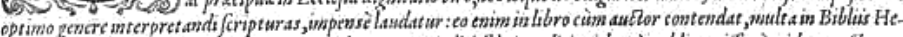

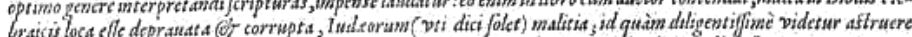

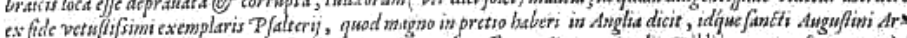

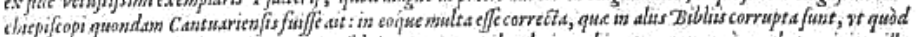

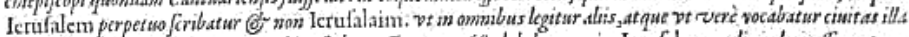

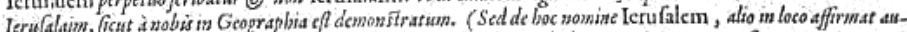
Elor iden magis quàm in illo hobro ) Deinde verò vaum affert locun ibidem, vt ait integre conferuatum, incecter is

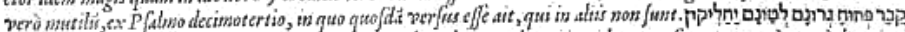

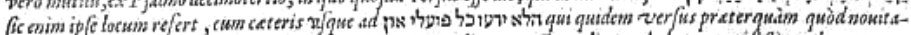

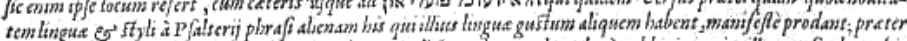

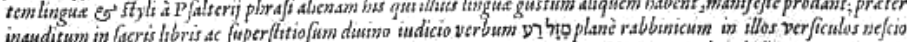

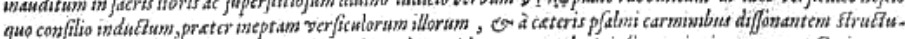

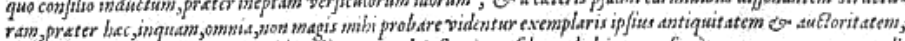

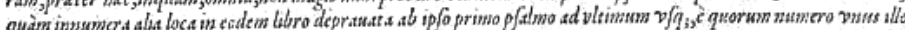

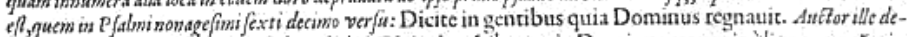

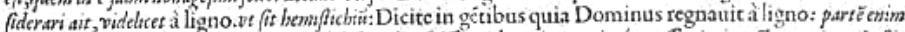

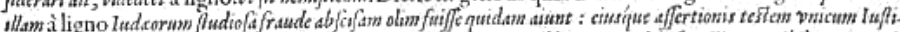

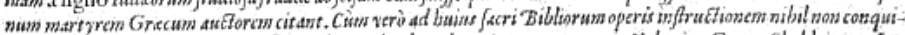

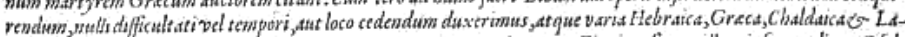

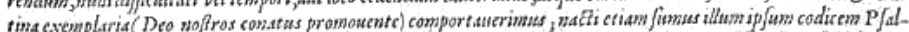

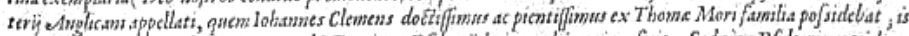

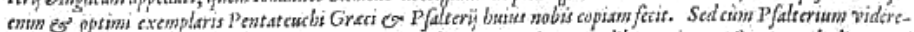

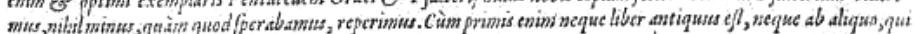

Fig. 3. Versión B de la Benedicti Ariae Montani De Psalterii Anglicani exemplari animaduersio, en Biblia Sacra Hebraice, Chaldaice, Graece et Latini Philippi II Regis Catholici pietate et studio ad Sacrosanctae Ecclesiae usum (Antuerpiae, 1569-1573), tomo VIII, tratado XIV, recto del folio, Biblioteca del Arzobispado de Sevilla, signatura 5-167. 
Hebrsicam linguam tenuerit, reitè defcriptus, verion à foriba Latinas proximè preteriticuiliteras pingendinon

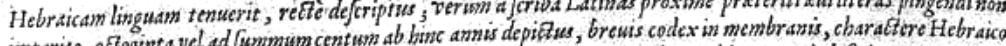

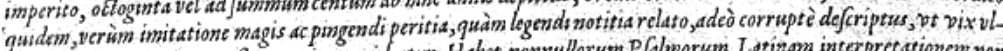
Tín vertum integritatem fum retinere videatur. Habet nonnullorum $\mathrm{P}$ falmorum Latinam interpretationem non nof tram vulgatam, fed mixtam quanda cum difunthionibus vel, vel, vel, es annotatiunculas cx variis expofito ribus breu:s, illum Iacobi de Valentia fylum redolentes. Cìm puerilem omnino rem effe deprehendiffem, tamen ad

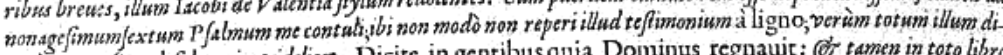
midrum ver/um defideraui, videlicet, Dicite in gentibus quia Dominus regnauit: \& tamen in toto libro quangwaim plara verba of integra jententie defiderentur, nibsl tamen deeft, quod fcriptum antea fuerit : constat

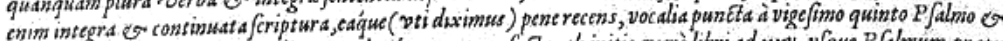
pltrà ex eodematramento, quo litere: codemíque tem pore fala, ab initio verò libri ad xxv. vfque P falmum, preter atramentum, minio obducta aut viridi colore, accentus nulli, quibufdam in locis Rapbe fatis crebra, quac accentus $\int p e$ ciem minus dilgenter intuentibus prebent: Capitales litere aliquot in P falmorum initios auree, rubre alie, virides quedam, ex belsotropio parpures multa; que tamen omnes Latinam magis quàm Hebream referint formam. Quod

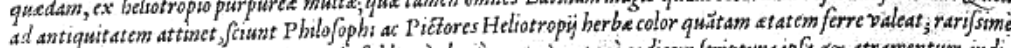
enim centcfimum integer attingit annü: fed longè clariùs recentem penè codicem fcripturs ipfa or atramentum indicat. Vt verò antiguorum ac ailigenter friptortom exemplarium fidem fanctam, ita buinf modi nullam effe oportuit, quamquam mille reperta effent, nedum vnius adeo noui, adeóque inepti. Quòd Sanqo eSugustino liber adf cribatur, ficres babet: In poftremis membranis pacantibus vocula quadam fcripta to modo funt, quo fcribere folemus, vbi calamum temperantes experimur, fed a foriptore literas pingendirudifsimo, inter alia verba ill a bis pofita funt Hic liber Sti Augu' Cantus. liber Sti Augu' Cant' : alque ille quifguis fuit foriptor, velalus, culsello abrafot ex priori loco Sti Augu' Cancu : o in pöferiori cesteris abrafis reliquit illud liber fa: ifo tamens a brafit, vo obiecita luci membrana leEtionem integram prodat, nam q; atramentum tenacius baferat, quàm 'pt ille delere potwerit, aut voluerit fortaffe. Hisc fcilicet aftimatio et auctoritas libro faEta eft: clarè enim legitur in pofferiori loco Liber Sa. religua ad lucem in rafa membrana leguntur. Ef deinde femiverficulus ex eodem charaaere fubiectus qui rbythmicerefpondet ad illud Liber fa. fed litera eft nefcio qua. Hec codicis antiquitas maie-

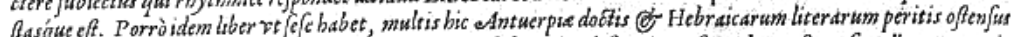
eft: redditusouc à nobis clementi ad quem pertinebas: fed eo vita defuncto, pofed ad nos efl rurfus allatus at que in bibliot beca noftra collocatus. Vt verò totius rei breue pecimen exbiberemus quod ad catera astimanda fatis effe poffet, cum ipfum nonagcfimum fextum $P$ falmum fideliffimè ad illam fidem defcriptum animaduerfoni buic nof tre a dprimendum curaumus. videat letior quantum cum veritate Hebraica, \& quantum etiam cum vulgati nof fra verforte quadrer.

PSALMVS XCVI.

Ex Clementis Angli exemplari defcriptus.

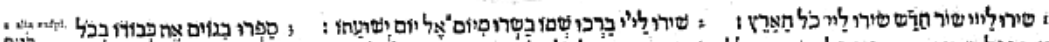

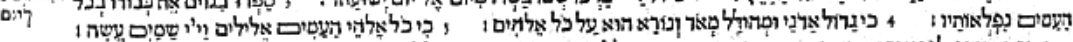

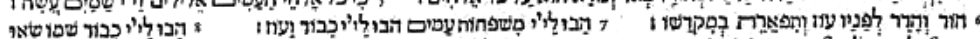

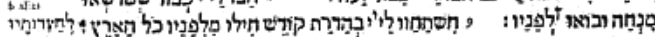

vetialim

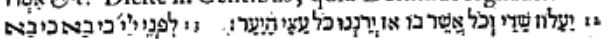

Principium verficuli to. decf, nempe

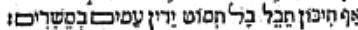

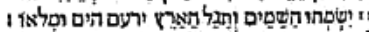
:

Fig. 4. Versión B de la Benedicti Ariae Montani De Psalterii Anglicani exemplari animaduersio, en Biblia Sacra Hebraice, Chaldaice, Graece et Latini Philippi II Regis Catholici pietate et studio ad Sacrosanctae Ecclesiae usum (Antuerpiae, 1569-1573), tomo VIII, tratado XIV, vuelto del folio, Biblioteca del Arzobispado de Sevilla, signatura 5-167. 


\section{RECORRIDO POSTERIOR DE LA POLÉMICA}

Los hechos expuestos en las páginas precedentes acontecieron entre 1572 y 1573. Según el testimonio de Arias Montano, Lindano parecía al principio satisfecho con la carta privada de retractación de febrero de 1573 y la nueva versión impresa de la Animaduersio, que iba mostrando allá por donde iba ${ }^{65}$. Pero lo cierto es que el teólogo neerlandés no debió de quedar muy conforme con la versión B de la Animaduersio por dos razones: en primer lugar aún circulaban muchos ejemplares de la Biblia con la primera versión de la Animaduersio, que presentaba a Lindano como un científico descuidado y falaz; por otro lado, en la segunda versión acordada entre Arias Montano y Lindano, el hebraísta español no había redactado de forma clara, como se ha estudiado aquí, el párrafo que contenía la acusación que había indignado a Lindano, de modo que la retractación quedó un tanto difuminada.

En su agria controversia con Lindano Arias Montano contó con la inestimable colaboración de un batallón de ilustres hebraístas vinculados todos a la edición de la Biblia Políglota. Entre 1574 y 1575 la correspondencia montaniana conservada en el manuscrito A 902 de la Biblioteca Real de Estocolmo revela la existencia de muy frecuentes contactos epistolares entre Lindano, por un lado, y, por otro, un núcleo duro de hebraístas formado por el profesor parisino Gilberto Genebrardo, el teólogo lovaniense Juan Harlemio, y el yerno de Plantino Francisco Rafelengio, quienes como colaboradores de la Biblia Políglota asumen también la defensa de Arias Montano. El tema principal de todo este comercio epistolar no es otro que la polémica sobre el valor y la veracidad de los originales hebreos de la Biblia ${ }^{66}$. Por esta época Lindano publica su libro titulado Meditationes in aureum illum Psalmum CXVIII (Colonia, 1575), un comentario cargado de contenido antihebraísta y que arremete de forma directa contra la metodología empleada en la Biblia Políglota de Amberes al insinuar que para la confección de la Biblia se debió de haber utilizado un códice hebreo corrupto. La última carta entre Arias Montano y Lin-

\footnotetext{
${ }^{65}$ Cf. carta de Arias Montano a Esteban de Salazar del 4 de febrero de 1594, en GonZÁlEZ CARVAJAL, «Elogio histórico», 191-192.

${ }^{66}$ Cf. DÁvila Pérez, «La polémica Arias Montano-Wilhelmus Lindanus: un nuevo documento», 150-151.
} 
dano conservada en el manuscrito de Estocolmo es del 13 de noviembre de 1575: en este documento aquel refuta los argumentos contenidos en la citada nueva obra de Lindano, pero concluye con un párrafo final que demuestra hasta qué punto seguía viva la controversia personal derivada de la publicación de la Animaduersio.

Quod uero quereris me tibi imposuisse quod affirmares illud «A ligno Deus» in Anglicano legi, affirmare me non memini. Memini tamen a me quaesitum in illo exemplari et non repertum, cum tamen unus locus sit qui a Dominatione Tua ex Iustino Martyre apud Hebreos legi affirmetur. Neque ego uiderim ubi Iustinus Hebraice lectum fuisse asserat; quamuis indicare uelit in septuaginta interpretum siue uersione siue paraphrasi quondam fuisse. Verum de hoc mihi laborandum nihil proposui, maxime cum illam praefationem in tui gratiam recuderim atque locum illum quo Dominatio Tua mihi semper obseruanda offendebatur ultro mutauerim. Paratus idem facere in iis omnibus quae non solum a te uiro doctissimo et mihi colendo, sed a quocunque modo uera monente doctus fuero ${ }^{67}$.

Ante todo causa estupor que, ante las renovadas quejas de Lindano derivadas de la poca claridad con la que Arias Montano había formulado su retractación en la versión B de la Animaduersio, el biblista español responda que no recuerda haber escrito que Lindano había afirmado que «a ligno Deus» se conservaba en el manuscrito inglés del salterio hebreo. La simple lectura de un ejemplar de la Biblia Políglota que contuviera la versión A de la Animaduersio podría haber refrescado la memoria de Arias Montano. A estas alturas de la polémica y a pesar de sus palabras, Arias Montano era muy consciente del error cometido; de lo contrario no habría accedido a la reimpresión de su Animaduersio, de la que habla en este mismo párrafo («maxime cum illam praefationem in tui gratiam recuderim atque locum illum quo Dominatio Tua mihi semper obseruanda offendebatur ultro mutauerim»). Su objetivo no parece ser otro que cerrar este desafortunado capítulo («Verum de hoc mihi laborandum nihil proposui»), aunque se muestra dispuesto a rectificar y cambiar en sus escritos todo lo que sea necesario («Paratus idem facere in iis omnibus quae non solum a te uiro doctissimo et mihi colendo, sed a quocunque modo uera monente doctus fuero»).

\footnotetext{
${ }^{67}$ Carta de Arias Montano a Lindano escrita desde Roma el 13 de noviembre de 1575 y publicada por Macías, La Biblia Políglota de Amberes, 452-455.
} 
Toda la polémica se seguía resumiendo en un solo punto: la necesidad de que Arias Montano admitiera, más claramente y de forma pública, que se había equivocado al afirmar en la Políglota que Lindano había dicho que el sintagma «a ligno» se conservaba en el salterio inglés. Entre los papeles de la carpeta 3714 del volumen «Manuscrits Divers» (I 115) del Algemeen Rijksarchief (Bruselas) se conserva una serie de documentos que en su día debieron de pertenecer a Lindano y que permiten proyectar nuestro conocimiento de la polémica que nos ocupa hasta finales de 1588 , cuando fallece el prelado neerlandés. Entre estos documentos se halla una copia a limpio de parte de la versión A de la Animaduersio montaniana: el contencioso entre ambos teólogos quedaba reducido al texto copiado, y más concretamente a los pasajes subrayados del mismo, que reproducimos en la ilustración de la página siguiente.

En 1579 Lindano escribe una dura carta de protesta a Felipe II en la que condensa su polémica con Arias Montano con una frase: «Y toda la cuestión se resume en esto, si Arias Montano ha dicho la verdad al asegurar que Lindano escribió y atestigua en su libro publicado que en cierto salterio hebreo anglicano leyó aquello del salmo "Reinó Dios desde el leño". Lo afirma Arias Montano; lo niega Lindano» ${ }^{68}$. El obispo neerlandés exige al rey de España que haga justicia rápida, pues era necesario restituir la fama a uno de sus dos ministros, mientras que el otro quedaría como mentiroso y calumniador. La presión de esta carta pudo influir en el encuentro que el cardenal Granvela organizó entre Lindano y Arias Montano en septiembre de 1579 en una celda del monasterio de El Escorial. Según el testimonio de Arias Montano, de aquel encuentro surgió una promesa que podría sellar la paz con Lindano:

Yo le juré que no habría hombre que con verdad dijese haberme oído decir de él menos que bien, y en esto me declaré tanto que me dijo: pues una cosa os pido, que en la primera obra que hiciereis, profeséis mi amistad y digáis que siempre me quisisteis bien, y de

\footnotetext{
${ }^{68}$ «In eo autem tota est quaestio, an Arias Montanus uerum dixerit, asserens Lindanum scripsisse ac testari edito in uulgus libro se in quodam anglicano Haebraico Psalterio illud Psalmi Regnauit a ligno Deus. Affirmat Arias Montanus; negat Lindanus». Cf. DÁvILA PéreZ, «Regnavit a Ligno Deus: Affirmat Arias Montanus; Negat Lindanus», 144-149.
} 


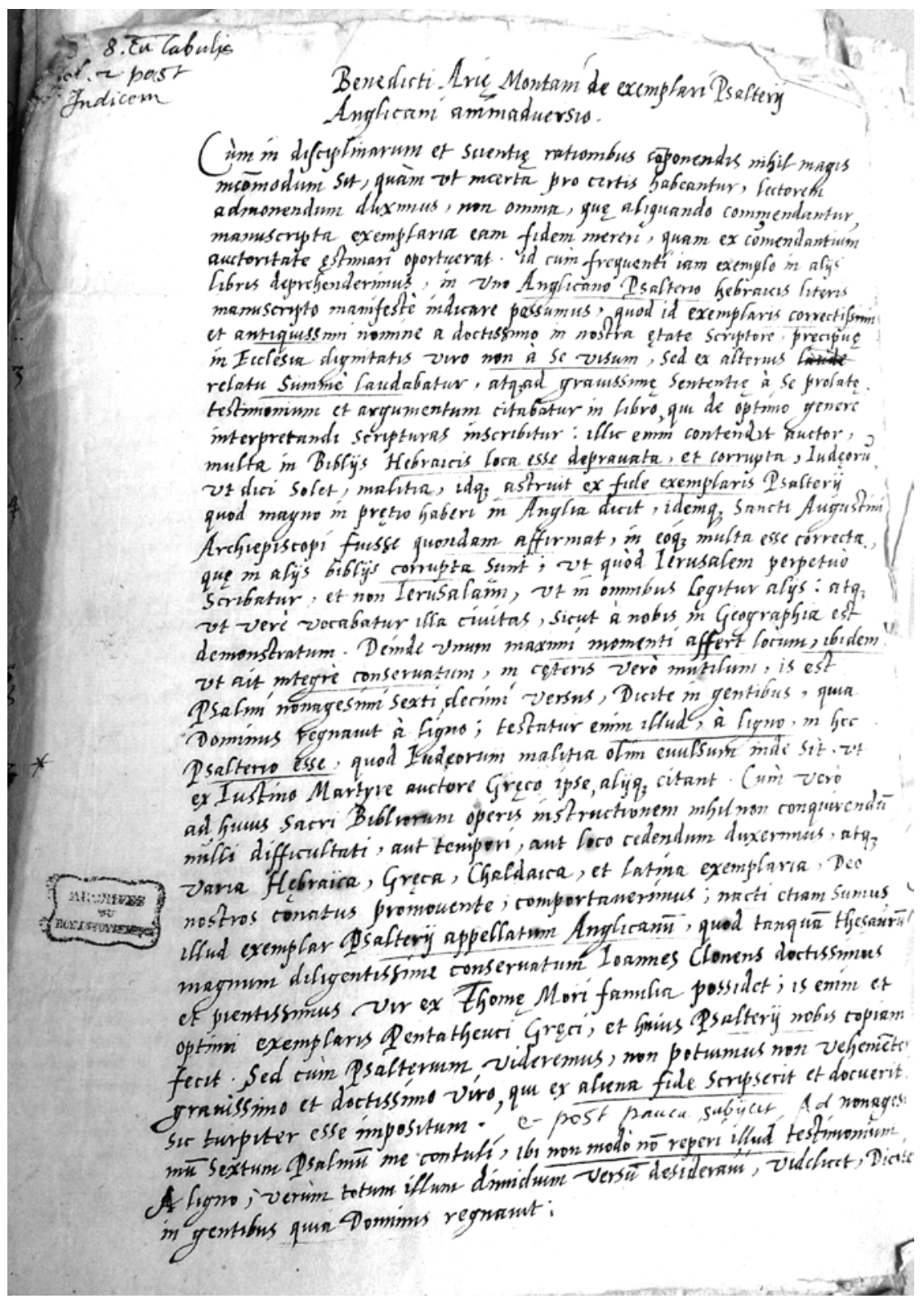

Fig. 5. Copia a limpio de parte de la versión A de la Animaduersio de Arias Montano. Archives Générales de Royaume / Algemeen Rijksarchief, Bruselas, «Manuscrits Divers» (I 115), 3714. 
esta manera cesarán los que piensan lo contrario; y le dije, yo se lo prometo $^{69}$.

Pero la realidad, de nuevo, fue algo distinta a como la contaba uno de sus protagonistas. Por los documentos conservados en los «Manuscrits Divers» (I 115) del Algemeen Rijksarchief sabemos que Arias Montano se comprometió a publicar un prefacio en su próxima obra impresa donde profesaría su amistad con Lindano pero, sobre todo, volvería a admitir, de forma más clara que en la versión B de su Animaduersio, que faltó a la verdad al afirmar que Lindano había escrito que leyó el sintagma «a ligno» en el manuscrito hebreo del salterio. Que esto fue así lo demuestra el borrador del texto latino que redactó Arias Montano en cumplimiento de su promesa, cuya traducción al castellano ofrezco a continuación:

Sed qualia huiusmodi de studiis laboribusque nostris iudicia fuerint, cum ea Ecclesiae Sanctae atque Catholicae arbitrio relinquamus, parum admodum laboramus. Illud nos tamen multis nominibus male habet, quod nonnulli sinistra scriptorum meorum interpretatione optimorum piissimorumque uirorum quos charos habeo, quibusque me charum esse noui, gratiam et beneuolentiam abalienare studuerint, ut qui ea quae aliquando de Psalterii Anglicani corrupta scriptura cum de exemplarium quorundam ratione atque iudicio scriberemus, indicabamus, eo prauitatis inflexerint, ut optimum doctissimum magnae autoritatis uirum, nobis cum praeci†puis $†$ aetatis nostrae pastoribus suscipiendum et perpetuo alias officio cultum, atque etiam colendum, mendatii insimulatum uel notatum intellexerint. His nos christianae pietatis plenam sanamque mentem optamus et persuasum uolumus nihil minus eo loco a nobis fuisse curatum, quam ut optimi praesulis dignitati autoritatique detraheretur, sed ut minima illi exemplari I fides deinceps haberetur. Quem cum aliter de exemplari illo sentire postea intellexissemus, utpote in quo ille numquam scripserit se illud hemistychion «regnauit a ligno Deus» legisse, admonitionem illam mutantes, locum quem non $\mathrm{ab}$ eodem exemplari illo defensum, non satis recte dixeramus, non in illo exemplari sed alibi lectum fuisse retulimus. Hoc est apud Iustinum Martyrem, qui ex antiquis graecis scriptoribus illius sententiae praecipuus autor est, non qui hebraeos in hebraicis exemplaribus, sed in graecis codicibus locum illum «regnauit a ligno Deus» mu-

\footnotetext{
${ }^{69}$ Cf. carta de Arias Montano a Esteban de Salazar del 4 de febrero de 1594, en GoNZÁLEZ CARVAJAL, «Elogio histórico», 192.
} 
tasse immo abstulisse dicat. Huiusmodi namque nostra fuit mens cum in illa admonitionis nostrae correctione scriberemus illum non in Anglicano codice sed alibi locum mutatum legisse «atque» in eodem Anglicano non dixisse integre conseruatum extare. Nam neque illum apud alios autores ex antiquis reperisse, neque non de illo aliter sensisse, neque alios scripta nostra aliter interpretatos esse par fuerat.

\section{[Añadido de otra mano:]}

Post diligentem collationem inuenta est haec copia concordare cum suo originali quod D[ominus] D[ominus] Arias Montanus sua manu propria scriptum una cum suis 1 [itte]ris ad R[euerendissi]mum D[omin]um Lindanum ex Regio Coenobio D[iui] Laurentii XXI septembris anno 1579 miserat. Quod idem autographum D[omini] D[omini] Ariae Montani R[euerendissim]us D[ominus] Lindanus postea aliquot locis in margine per $1[$ itte]ras $\alpha, \beta, \gamma$, insertas castigauit in hunc modum: $\alpha$ utpote in quo ille numquam scripserit se illud hemistichion «regnauit a ligno Deus» legisse; $\beta$ immo abstulisse; $\gamma$ atque in eodem Anglicano non dixisse integre conseruatum extare. Per me Eugenium Gherinx V[triusque] I[uris] L[icenciatum] et sacris ap[osto]lica et im[peria]li auct[oritatibu]s Notarium ${ }^{70}$.

\section{[Traducción]}

Pero muy poco nos preocupamos por qué opiniones de este tipo ha habido sobre nuestros estudios y trabajos, puesto que los dejamos al juicio de la Iglesia Santa y Católica. No obstante nos molesta por muchas razones lo siguiente, que algunos se afanaron con una aviesa interpretación de mis escritos por quitarme la gracia y la benevolencia de los mejores y más piadosos señores, a los que quiero y por los que sé que soy querido, puesto que lo que declarábamos en su día sobre la escritura corrupta del salterio inglés al escribir acerca de la valoración y juicio de algunos ejemplares, lo distorsionaron con tal grado de maldad que entendieron que se marcaba y acusaba falsamente de mentiroso a un óptimo señor doctísimo de máxima autoridad, que yo debo tener entre los principales pastores de

${ }^{70}$ Copia del prefacio escrito por Arias Montano y enviado a Lindano con fecha del 21 de septiembre de 1579, conservada en Archives Générales du Royaume / Algemeen Rijksarchief (Bruselas), «Manuscrits Divers», I 115, 3714. 
nuestra época y, por lo demás, reverencio con perpetuo oficio e incluso admiro $^{71}$. Con estas palabras nosotros deseamos una actitud sana y llena de piedad cristiana, y queremos que quede persuadido de que en absoluto pretendimos en ese lugar restar autoridad a la dignidad del óptimo obispo, sino que se prestara en adelante la menor credibilidad a aquel manuscrito. Habiendo sabido después que aquél tenía otro parecer de ese manuscrito $^{72}$, puesto que él nunca había escrito que hubiera leído en ese códice el hemistiquio «Reinó Dios desde la cruz», cambiando aquella advertencia, referimos que el lugar que habíamos dicho de forma no muy acertada que él había defendido en aquel mismo ejemplar, no había sido leído en aquel ejemplar, sino en otro sitio, esto es, en el Mártir Justino, que entre los escritores griegos antiguos de esa opinión es el principal autor que diga que los hebreos han cambiado sino incluso suprimido aquel lugar «Reinó desde la cruz Dios» no en los ejemplares hebreos, sino en los códices griegos. De tal clase fue, pues, nuestra intención al escribir en la corrección de nuestra advertencia ${ }^{73}$ que aquel no había leído el lugar modificado en el códice anglicano, sino en otro lugar, y que no había dicho que en ese mismo códice anglicano estuviera conservado de forma completa. Pues no había sido posible ni que él lo hubiese encontrado entre otros autores de los antiguos, ni que nosotros no hubiéramos tenido otra opinión sobre él, ni que otros hubieran interpretado nuestros escritos de otra manera.

\section{[Añadido, de otra mano:]}

Después de un cuidadoso cotejo se encuentra que esta copia concuerda con su original, que el señor Arias Montano escrito de su propia mano había enviado al reverendísimo obispo Lindano con su carta desde el Monasterio de San Lorenzo el 21 de septiembre de 1579. Que el mismo autógrafo del señor Arias Montano el reverendísimo señor Lindano después corrigió en algunos lugares por medio de la inserción de las letras $\alpha, \beta, \gamma$ de la siguiente manera: $\alpha$ puesto que él nunca había escrito que hubiera leído en ese códice el hemistiquio «Reinó Dios desde la cruz»; $\beta$ sino incluso suprimido; $\gamma$ y que no había dicho que en ese mismo códice angli-

\footnotetext{
${ }^{71}$ Como ocurre en las dos versiones de la Animaduersio Arias Montano vuelve a aludir, sin citar su nombre, a Guillermo Lindano.

${ }^{72}$ Con esta frase liquida Arias Montano toda la polémica que suscitó la publicación del texto de la versión A de la Animaduersio.

${ }^{73}$ Se refiere aquí Arias Montano a la versión B de la Animaduersio.
} 
cano estuviera conservado de forma completa. Por mí, Eugenio Gherinx, Licenciado en Ambos Derechos y Notario por las autoridades apostólica e imperial.

El texto conservado es una copia certificada ante notario, quien da fe de que se corresponde con el original de Arias Montano y que hace constar que el documento original ha sido ampliado con tres añadidos por parte de Lindano. El obispo de Roermond no quería incurrir en el mismo error cometido en la segunda versión de la Animaduersio, donde Arias Montano había ofrecido una retractación no del todo satisfactoria. En esta nueva ocasión quería controlar de cerca el texto desde su fase de borrador hasta la propia impresión, con la mediación de un notario que confiriera legalidad a todo el proceso. A tales límites había llegado la desconfianza entre las dos partes en liza.

Sea como fuere, Arias Montano no llegó a publicar esta nueva retractación ni el tratado en cuyo prefacio debería ir insertada ${ }^{74}$. Como consecuencia de ello, Lindano no dejó de exigir la restitución de su fama ni de acosar la de aquel. Entre los papeles de la carpeta I 1153714 del Algemeen Rijksarchief de Bruselas se conservan cartas que muestran cómo Lindano se coordinó con teólogos de los Países Bajos, como Enrique de Grave, Juan Molano y Jacobo Jansonio, así como con el salmantino León de Castro, no solo para tratar de buscar evidencias sobre el carácter judaizante de la Biblia Políglota, sino también para atacar la heterodoxia de otros muchos pasajes de la obra exegética de Arias Montano ${ }^{75}$. Por su parte, este, que contaba con el favor de reyes, obispos, cardenales y gran parte de la erudición del momento, movía todos hilos para que los ataques del obispo flamenco contra la Biblia y sus escritos quedaran neutralizados o directamente acallados.

La prueba más evidente de que detrás de las manifestaciones tópicas de amistad entre ambos teólogos se desarrolló una guerra sin

\footnotetext{
${ }^{74}$ En uno de mis trabajos anteriores he tratado de reconstruir el contenido de este tratado; cf. DÁvIla Pérez, «Retractación o pertinacia», 399-410.

${ }^{75}$ Véanse las cartas de León de Castro a Lindano del 16 de septiembre de 1579, 28 de agosto de ese mismo año; y septiembre de 1579; de Juan Molano a Lindano del 19 de junio de 1584; de Enrique de Grave a Lindano del 2 de febrero de 1586; y de Jacobo Jansonio a Lindano del 10 de abril de 1586. Cf. DÁvila Pérez, «Regnavit a Ligno Deus: Affirmat Arias Montanus; Negat Lindanus», 150-161, 168-183.
} 
cuartel por la propia fama se encuentra, de nuevo, en la valiosa carta de 1594 donde Arias Montano ofrece su versión de toda polémica: cinco años después de que el obispo neerlandés hubiera abandonado este mundo, el director de la Políglota aduce, inexplicablemente, la misma falsa denuncia que casi le costó un proceso eclesiástico de clerico maledico, por la que hubo de reimprimir uno de sus prefacios de la Políglota y de la que fue obligado a retractarse ante Lindano varias veces a lo largo de su vida: «Y para esto como cosa singular, y como dicen argumento palmario, y testigo más que de vista citó Lindano un Psalterio, que él mismo llamó anglicano, por incorrupto y muy entero y antiguo, e las demás calidades que él puso, en el cual afirmó estar el Dicite in gentibus, quia Dominus regnauit a ligno; y otro verso que decía faltar en los otros ejemplares [...] Fuimos a buscar el medio verso o final de el a ligno y no solo faltaba el a ligno, sino todo lo que respondía Dicite in gentibus quia Dominus regnauit ${ }^{76}$. Arias Montano, que se quejó en su tiempo de que Lindano hablara mal de los ausentes, no tenía inconveniente en hablar mal y reproducir una falsa calumnia sobre un enemigo científico que ya había fallecido.

\section{CONCLUSIONES}

El origen de la controversia entre Lindano y Arias Montano es, por encima de las divergencias entre hebraístas y «miso-hebraístas», un caso de falsa acusación por un descuido de Arias Montano y su equipo. En una lectura acelerada del tratado De optimo scripturas interpretandi genere de Lindano, el editor en jefe de la Políglota había entendido que Lindano afirmaba que las palabras «a ligno» se conservaban en un manuscrito hebreo del salterio que, pese a ser alabado por el obispo neerlandés, según los expertos hebraístas reunidos en la casa plantiniana no pasaba de ser un ejemplar reciente y sin gran valor. Tras la preceptiva consulta de dicho manuscrito, Arias Montano pudo comprobar que tal expresión no se conservaba allí, lo que llevaba al biblista español a creer que Lindano ni siquiera había visto con sus propios ojos el ma-

\footnotetext{
${ }^{76}$ Cf. carta de Arias Montano a Esteban de Salazar del 4 de febrero de 1594, en GoNZÁLEZ CARVAJAL, «Elogio histórico», 190.
} 
nuscrito que elogiaba. Estas dos acusaciones articularon la versión A del texto publicado en el tomo octavo de la Políglota con el título $D e$ Psalterii Anglicani exemplari animaduersio, versión que debió de ser impresa entre enero y abril de 1572.

Pero el caso es que Lindano sabía perfectamente que el sintagma «a ligno» no se conservaba en el manuscrito hebreo del salterio. En este trabajo hemos revisado cómo el obispo neerlandés solo había citado las palabras «a ligno» no en referencia al manuscrito del salterio, sino como un ejemplo alegado desde san Justino para demostrar el valor de la Septuaginta, que conservaba este texto, frente a los ejemplares en los que se sustentaba la verdad hebraica, que lo habían perdido.

El error de Arias Montano fue tan flagrante que, ante las amenazas de Lindano de incoar un proceso eclesiástico por difamación, el biblista español hubo de avenirse a una retractación consensuada. Después de todo, la Biblia Políglota, como apunta Natalio Fernández Marcos, pretendía ser un monumento a la concordia ${ }^{77}$, y la concordia debía comenzar por las propias filas católicas. Todo esto desemboca en la versión B de la Animaduersio, que debió de ser redactada e impresa entre abril y agosto de 1573. En este texto Arias Montano corrige las dos acusaciones más importantes que habían indignado a Lindano, pero lo hace de una forma intencionadamente ambigua, cerrando así en falso su controversia con el prelado neerlandés.

A partir de 1573 y hasta el día de su muerte, Lindano lleva a cabo una persecución sin tregua a Arias Montano. Su objetivo era la publicación de un nuevo texto en el que el biblista español admitiera con total claridad que Lindano no había dicho que el sintagma «a ligno» se encontraba en el manuscrito inglés. En 1579 Montano redacta un nuevo escrito para complacer las exigencias de su pertinaz émulo. Para evitar que Montano publicara una nueva retractación no satisfactoria, como la de la versión B de la Animaduersio, Lindano corrige personalmente el borrador de Arias Montano y se sirve de un notario que certifica la veracidad de la copia y la inclusión de añadidos

\footnotetext{
${ }^{77}$ Cf. N. Fernández Marcos, «La Biblia Regia de Arias Montano: ¿Biblia de la concordia o Biblia de la discordia?», en MARQUÉs DE LA ENCOMIENDA - C. Solís RodríGUEZ - F. Tejada Viruete - M. Terrón (eds.), El Humanismo extremeño II. Jornadas organizadas por la Real Academia de Extremadura en Fregenal de la Sierra 1997 (Trujillo, 1998), 105-122.
} 
por parte del quejoso. Esta retractación definitiva, que debía ver la luz en el prefacio de alguna de las obras montanianas, no fue jamás publicada.

La Animaduersio fue impresa en un lugar de gran visibilidad de la Políglota de Amberes con la intención de dar un golpe de gracia a los detractores del original hebreo del Antiguo Testamento, encarnados en la obra de Lindano. Pero el desliz cometido al leer el tratado de Lindano hizo que el ataque se volviera, a modo de bumerán, contra la Políglota y su director. El resto, hasta la muerte de los implicados, se puede resumir en la frase escrita por Lindano en su carta de protesta a Felipe II: «Regnauit a ligno Deo. Montanus affirmat; Lindanus negat».

Recibido: $10 / 03 / 2014$

Aceptado: 30/05/2014 